\title{
Antimicrobial Peptides: New Frontiers in the Therapy of Infections
}

\author{
Mario Zucca, Sara Scutera and Dianella Savoia \\ University of Torino \\ Italy
}

\section{Introduction}

The discovery of antibiotics unquestionably represents a major achievement in the treatment of infectious diseases. However, the early optimistic expectations to definitely win the war against infections have not been met, mainly because of bacterial resistance, that has evolved to each antibiotic introduced into clinical practice and complicates infections in more vulnerable individuals, such as organ transplant receivers, AIDS, hemodialysis, and cancer patients. The development of resistance is inherent to the mechanism of action of classic antibiotics, that target specific bacterial enzymes, and could be overcome by new antibiotics with different targets, but in the last 40 years very few new antibiotics have reached the market. Indeed, the great majority of antibiotics presently in use for systemic infections derives by synthetic tailoring from a limited number of dated molecular scaffolds (Fischbach \& Walsh, 2009). The wide-spread use of antibiotics for both medical and nonmedical purposes prompted the emergence of a number of multi-resistant bacterial strains, such as methicillin-resistant Staphylococcus aureus (MRSA), vancomycin-resistant Enterococci, Acinetobacter baumannii, Escherichia coli, carbapenem-resistant Klebsiella pneumoniae and Pseudomonas aeruginosa, Clostridium difficile, and Mycobacterium tuberculosis. Epidemic resistance to antibiotics has been described for a number of superbug pathogens, such as MRSA, Streptococcus pneumoniae and Mycobacterium tuberculosis, and multidrug- or panresistant gram-negative bacilli (Spellberg et al., 2008). It is estimated that infectious diseases, despite the availability of antibiotics, remain the second-leading cause of death worldwide (World Health Organization, 2004). On the other hand, the development of new drugs is considered no more fashionable by the pharmaceutical industry, due to the low probability to recover the huge investments required to license new antibacterials that will be used in a low number of selected infections. Indeed, this high cost-low revenue perspective made many large pharmaceutical companies to quit antibiotic discovery for more profitable therapeutics. That being said, let us approach the subject by reviewing the Pub-med literature regarding the up-to-date research on natural and synthetic antimicrobial molecules of proteinaceous nature, as alternatives to conventional antibiotics. Since the mid1990s, bacterial genome sequencing was carried out with the aim to identify new bacterial targets. High-throughput target-based screening and combinatorial chemical libraries were developed, but after some time it was realized that the results were not up to the expectations, for at least three reasons: first, most enzymes essential for bacterial viability can not be easily affected by drugs; second, some of the structures that would be the best 
antibacterial targets (e.g. ribosomes and nascent peptidoglycan) are not accessible to in vitro screening; and third, chemical libraries do not have the molecular complexity of naturally produced antibiotics (Baltz, 2008). To illustrate the difficulties relative to the new targets approach, scientists at GlaxoSmithKline reviewed the outcome of an extensive program of screening chemical libraries against multiple potential Gram-positive or broad spectrum targets over a period of seven years (Payne et al., 2007). Out of the 300 genes evaluated, 160 were found to be essential for viability. The screen against 67 target proteins covering a wide range of cellular metabolic activities yielded 16 hits, but only 5 yielded leads. Of these, only two (3\%) were identified as potentially new targets. The authors noted that results were unsustainably poor in relation to the effort (Baltz, 2008). Because of these difficulties, the recent trend is to look for new antimicrobials by screening natural products, that are an inexhaustible source of bioactive compounds. Technical advances in genomics, bioinformatics, microbial ecology, synthetic biology, and systems biology offer new opportunities for multidisciplinary approaches to small molecule discovery (Davies, 2011; Walsh \& Fischbach, 2010). The reserve of natural molecules produced by bacteria, fungi, plants, and vertebrates can offer both novel antibiotics that work in the classic way, and new antimicrobials that being based on different molecular scaffolds will more easily bypass resistance. Most of these natural substances are of peptidic nature and work by targeting conserved mechanisms, often shared by more than one pathogen. Antimicrobials of peptidic nature can be divided into two classes: the gene-encoded, ribosomally synthesized peptides, and the non-ribosomally synthesized peptide antibiotics, typically produced by bacteria and fungi. The latter are assembled by multi-enzyme complexes, contain d-amino acids and other non-proteinogenic amino acids, and often have a cyclic or branched structure (Wiesner \& Vilcinskas, 2010). Some members of this class already on the market, such as bacitracin, gramicidin S, polymyxin B, the streptogramins, vancomycin and teicoplanin have limited clinical use, mostly because of toxicity, poor solubility, or limited spectrum of activity. The ribosomally synthesized antimicrobials (none of which is yet on the market) can be subdivided into two further classes depending on their source: the term "antimicrobial peptides" (AMPs) strictly speaking indicates peptides of eukaryotic origin, whereas peptides and proteins produced by bacteria are called bacteriocins. However, considering the similarities in terms of structure and mechanism of action, in this chapter the term AMPs will be used to globally indicate members of both classes. With this premise, we can say that AMPs are widely conserved, small amphiphilic antagonistic molecules produced by both prokaryotic and eukaryotic organisms. Bacteria secrete microcins and bacteriocins that inhibit bacterial food competitors present in the same environment, whilst plants and insects, that lack the adaptive immune response, rely on AMPs for protection against infections (Scott et al., 2008). In mammals, AMPs are present in neutrophils and on skin and mucosal surfaces, where they carry out direct antimicrobial activity and participate to the innate immune response (Maroti et al., 2011). The concept of developing AMPs as potent pharmaceuticals for human therapy dates back to the 1990s (Chopra, 1993), and most research articles since then published on this topic conclude by stating that AMPs represent promising therapeutic agents against bacterial, fungal, viral and parasitic diseases. Today the issue is more relevant than ever, due to the occurrence of two concomitant factors: the emergence of multi- or pan-drug-resistant bacterial strains, and the availability of new and sophisticated technical approaches to design, engineer and optimize AMPs for every specific application. The challenge is to design synthetic mimics that maintain the potency of natural AMPs, able to kill pathogens in the low micromolar concentration range, but lose some 
flaws of natural molecules, such as low stability, immunogenicity, low bioavailability, and production cost (Sharma et al., 2009). According to their electrical charge, AMPs can be divided into anionic and cationic peptides. Anionic AMPs (AAMPs), found in vertebrates, invertebrates and plants, are active against bacteria, fungi, viruses, nematodes and insects. Their net negative charge ranges from -1 to -7 , and their length from 5 to about 70 amino acid residues. In comparison with cationic AMPs (CAMPs), AAMPs have received little attention in the literature, and their mechanism of action so far has not been elucidated. For an outline of AAMP characteristics, the interested reader is referred to the exhaustive review by Harris et al. (2009). Vertebrate CAMPs can be also defined "host defense peptides" (HDPs), because beyond their direct antimicrobial activity, in vivo they often modulate the host immune response (Hölzl et al., 2008). By inducing chemokine and cytokine production, HDPs can recruit and activate immune cells, stimulate wound repair, and promote or inhibit angiogenesis (Wilmes et al., 2001). Moreover, certain CAMPs, such as amphibian temporins, neutralize bacterial endotoxins (Mangoni \& Shai, 2009), and some of them, such as cecropin, buforin and magainin also exhibit selective direct cytotoxic activity against different types of human cancer cells (Schweizer, 2009). Typically, CAMPs are gene-encoded peptides derived from larger precursors by proteolytic processing, are 12-50 amino acid long with a net positive charge of +2 to +11 , due to an excess of basic arginine and lysine residues, and have approximately 50\% hydrophobic amino acids (Finlay \& Hancock, 2004). Based on their molecular and conformational structure, CAMPs can be divided into four classes: cysteinerich $\alpha$-sheet structures stabilized by two to four disulphide bonds (human $\alpha$ - and $\beta$ defensins, plectasin, protegrins); linear $\alpha$-helical peptides without disulphide bonds (cecropins, magainins and dermaseptins); loop-structured peptides with one disulphide bond (bactenecin, microcins from Enterobacteriaceae), and extended structures rich in glycine, tryptophan, proline, arginine and/or histidine (cathelicidins, indolicidin) (Hancock \& Sahl, 2006). So far, more than fifteen hundreds AMPs have been identified; an updated AMP database is available on line at: http://aps.unmc.edu/AP/main.php (Wang G. et al., 2009). Positively charged CAMPs interact with the negatively charged microbial surface, and the interaction disrupts the membrane barrier function via pore-formation or unspecific membrane permeabilization. Different models, such as the toroidal pore (magainins) and barrel stave (alamethicin) models, which imply the formation of pores, or the carpet-like model (cecropins), in which the cell membrane is disintegrated and/or micellized, have been proposed to describe the structures formed between peptides and membrane phospholipids. The difference between the anionic charge of bacterial membranes and the neutral charge of mammalian cell membranes rich in zwitterionic phospholipids or cholesterol may help to explain the selectivity of action of many CAMPs (Wilmes et al., 2011). Bacterial killing is mediated by membrane disorganization, taking seconds to minutes, and/or by the binding to intracellular targets, that takes more time (3-5 hours). None mechanism is receptor-based, consistent with the finding that D-peptides are generally as active as L-peptides (Scott et al., 2008). AMPs show a highly conserved amphiphilic topology, with the hydrophilic and hydrophobic side chains segregated into distinct opposing regions or faces of the molecule. This topology is essential for insertion into and disruption of bacterial cytoplasmic membranes, and physicochemical properties, rather than any precise amino acid sequence, are responsible for AMP activity (Scott et al., 2008). Even non-peptidic compounds with amphiphilic structures, such as ceragenins, cholic acid derivatives, or polymers with phenylene ethynylene, polymethacrylate, $\beta$-lactam, or 
polynorbornene backbones, are effective broad spectrum antibacterials (Chin et al., 2007; Lai XZ. et al., 2008). These compounds are not currently developed, but their low cost, ease of production and non-toxicity for mammalian cells make them suitable for sterile clothing and biocompatible medical materials, such as catheters, sutures and indwelling devices (Gabriel \& Tew, 2008).

\section{Mammalian defensins}

Defensins are the prototypic mammalian HDPs. The presence inside neutrophil granules of proteins able to kill microorganisms with an oxygen-independent mechanism has been described in the 1980s (Ganz et al., 1986). Since then, defensins have been intensively investigated, and by now the family includes many structurally related peptides found in vertebrates, fungi, plants and insects. The discovery of defensin-like peptides produced by the myxobacteria Anaeromyxobacter dehalogenans and Stigmatella aurantiaca, demonstrated by in silico analysis, suggests that eukaryotic defensin genes are highly conserved (Zhu, 2007). Vertebrates express three defensin mature peptide subfamilies, defined $\alpha, \beta$, and $\theta$, with sequences of 29-35, 35-45, and 18 amino acids, respectively. Defensins are synthesized as 'prepropeptides' which are processed to various degrees depending on the expression site. The $\alpha$ - and $\beta$-defensins are products of distinct gene families evolved from an ancestral $\alpha-$ defensin gene that is expressed in species as ancient as venomous snakes (Selsted \& Ouellette, 2005). Defensins $\alpha$ and $\beta$ show a similar tertiary structure with triple-stranded $\beta$ sheet domains, but differ by the linear spacing and disulfide pairings of their six conserved cysteine residues. The $\theta$-defensins, first observed in Macaca mulatta leukocytes, are the product of a post-translational head-to-tail ligation of two truncated $\alpha$-defensins, resulting in cyclized octadecapeptides stabilized by three disulfide bonds. They are the only known cyclic polypeptides of mammalian origin, and are present in several species of Old World monkeys and in orangutans but not in humans or New World primates. Although humans express mRNA encoding $\theta$-defensin orthologs, mutations that introduce stop codons into the otherwise open reading frame of the $\theta$-defensin precursors abolish the peptide production (Penberthy et al., 2011). Defensins are directly active against a broad spectrum of bacteria, fungi, protozoa and enveloped viruses, and indirectly concur to host defense processes such as inflammation, angiogenesis and tissue healing (Penberthy et al., 2011).

Six a-defensins encoded by five genes have been identified in humans: HNP (human neutrophil peptide)- 1 to -4 , and HD (human defensin)- 5 and -6 . HNP-2 is a truncated form of HNP-1 or HNP-3 peptides (Wiesner, 2010). HNP 1-4 are produced by neutrophils, whereas HD-5 and HD-6 are synthesized and secreted by Paneth cells, a specialized form of epithelial cells that are found at the base of the crypts of Lieberkühn in the small intestine. On stimulation through Toll-like receptor-2, -3 , and -5 , neutrophils and Paneth cells release stored $\alpha$-defensins to the extracellular milieu, where they exert their antimicrobial activity.

At least 33 human $\beta$-defensin genes have been discovered (Schutte et al., 2002), but so far only four human $\beta$-defensins (hBD-1 to -4 ) have been characterized in mucosal and epithelial cells. In addition to their antimicrobial properties, $\beta$-defensins recruit immature dendritic cells and $\mathrm{T}$ cells, and stimulate the maturation of antigen-presenting cells (McCormick \& Weinberg, 2010). The expression of hBD-2 increases upon stimulation of numerous cell types with LPS or proinflammatory cytokines, whereas hBD-1 constitutive expression is not affected (Ryan at al., 2011). Human $\alpha$ - and $\beta$-defensins contribute to maintain a stable commensal microbiota in the intestinal tract, preventing bacterial 
overgrowth. It is hypothesized that reduced defensin concentrations compromise host defense and predispose to ileal and colonic Crohn disease (CD) (Ramasundara et al., 2009). Patients with ileal CD are characterized by decreased expression of Paneth cell HD-5 and -6, whereas colonic $\mathrm{CD}$ is characterized by attenuated induction of $\beta$-defensins. On the contrary, in ulcerative colitis there is substantial evidence to support a significant upregulation of the inducible $\beta$-defensins. Production difficulties, cell toxicity and concerns on the possible dysregulation of the tissue cytokine milieu have so far hindered the development of human defensins for therapeutic use (Chen H. et al., 2006; Kougias et al., 2005; Wencker \& Brantly, 2005). Therefore, the defensin most promising for medical use is plectasin, a 40-amino acid peptide produced by the fungus Pseudoplectania nigrella (Mygind et al., 2005). Plectasin is active against S. pneumoniae and S. aureus, including penicillinresistant strains, but weakly cytotoxic on mammalian cells. This selectivity is probably due to its recently clarified mechanism of action, that does not involve cell membrane disruption, but targets lipid II, a bacterial cell wall precursor (Schneider et al., 2010). Plectasin and one of its variants, the peptide NZ2114, are currently under development by Novozymes A/S as lead compounds to be used against vancomycin- and methicillinresistant $S$. aureus (Brinch et al., 2010).

The presence of remarkably intact $\theta$-defensin pseudogenes in humans, and the wide spectrum of antimicrobial activity of monkey $\theta$-defensins, made these molecules the subject of extended research, that brought to the production of the human corresponding peptides, called "retrocyclins" (RCs), by using solid-phase synthetic approaches. RCs are synthetic, humanized $\theta$-defensin cyclic octadecapeptides, active against HIV and herpes and influenza viruses, and able to neutralize anthrax toxin. RC-1, -2 and -3 prevent the entry of HIV-1 into target cells by blocking the virus envelope-cell membrane fusion. Studies are underway to develop RCs as local microbicides to prevent HIV-1 transmission. To this end, it has been observed that amino acid substitutions can be introduced into the RC backbone to improve the anti-HIV activity (Penberthy et al., 2011). RCs also have bactericidal activity, which makes them promising candidates for further development as topical microbicides to prevent bacterial sexually transmitted diseases. Following the observation that in eukaryotic cells aminoglycosides induce a low level of translational misreading, which suppresses the termination codon through the incorporation of an amino acid in its place, Venkataraman et al. utilized aminoglycosides to induce translational read-through of the $\theta$-defensin pseudogene, which restored the expression of functional anti-HIV-1 retrocyclin peptides in human cervicovaginal tissue models (2009). These authors suggest that the topical application of aminoglycosides to induce the production of endogenous retrocyclins by the vaginal mucosa might soon become an effective method to combat HIV-1 sexual transmission. However, the field of RC applications is intended to widen, because it has been observed that Rhesus $\theta$-defensin protects mice from SARS coronavirus pulmonary infection (Wohlford-Lenane et al., 2009), and that RC-2 protected both MDCK cells and chicken embryos from infection by the H5N1 avian influenza virus (Liang et al., 2010). The issue of the still prohibitive RC production cost is being addressed by Lee et al. by the use of chloroplasts as bioreactors. These authors developed a technique based on the use of chloroplast transformation vectors that allows the production of RC-101, a non-hemolytic and minimally cytotoxic RC-1 analogue with good anti-HIV-1 activity, and of protegrin-1 (a 18-residue AMP discovered in porcine leukocytes, that showed potent antimicrobial activity 
against bacteria, fungi and yeasts) by tobacco chloroplasts (Lee et al., 2011). The process allows the production of adequate quantities of purified peptides to be used in preclinical studies. RCs share remarkable structural and functional similarity with other small hairpin peptides of 17-18 amino acids found in diverse species. Three groups of such peptides are gomesins, protegrins and tachyplesins/polyphemusins, which were isolated from spider hemocytes (Silva et al., 2000), porcine leukocytes (Storici \& Zanetti, 1993), and horseshoe crab hemocytes (Nakamura et al., 1988), respectively. Gomesins, $\beta$-hairpin peptides consisting of 18 amino acids with two disulfide bridges, are active against fungi, bacteria, protozoan parasites and tumor cells (Moreira et al., 2007; Rodrigues et al., 2008). Protegrins are cysteine-rich, 18-residue $\beta$-hairpin peptides with 2 disulfide bridges, and show potent broad-spectrum activity that targets bacteria, filamentous fungi, yeast cells, and HIV-1 (Bulet et al., 2004; Cole \& Waring, 2002). Tachyplesins are 17-18 amino acid peptides with a C-terminal alpha-amide group that forms a rigid 2-stranded anti-parallel $\beta$-sheet structure connected by a $\beta$-turn. Natural tachyplesins exhibit potent antibacterial and antifungal activity and modest anti-HIV activity, but unfortunately they lyse human erythrocytes (Penberthy et al., 2011).

\section{Cathelicidins}

Cathelicidin discovery can be traced back to the isolation of an antimicrobial disulfidecontaining cyclic dodecapeptide from bovine neutrophils (Romeo et al., 1988), soon followed by the purification of two additional peptides, designated bactenecins (after the Latin words 'bacterium necare'), and of conserved similar proteins in other species (Zanetti, 2005). The term 'cathelicidins' was proposed in 1995 to acknowledge the evolutionary relationship of the novel protein family to cathelin, a protein originally isolated from porcine neutrophils as an inhibitor of cathepsin L, and it is used to denote holoproteins containing a conserved N-terminal cathelin-like domain of 99-114 residues linked to a heterogenic C-terminal antimicrobial domain of 12-100 residues ( $\mathrm{Zhu}, 2008)$. The C-terminal peptides exert direct and/or indirect antimicrobial activity following their cleavage from the holoprotein (Zanetti, 2005).

\subsection{Mammalian cathelicidins}

Cathelicidins have been found in every mammal examined, with substantial interspecies variation in the number of members. The only human cathelicidin so far identified, also defined human cationic antimicrobial peptide-18 (hCAP18), has been isolated from neutrophils in 1995, and its expression has been successively observed in skin, mucous epithelia, wound and blister fluid, and in seminal plasma (Zanetti, 2005). The coding gene is located on chromosome 3, and its expression is both constitutive (in sweat gland cells) and inducible by vitamin D3, LPS and butyric acid (in colonic epithelial cells) (White, 2010). Unlike neutrophil defensins, which are fully processed to mature peptides before storage in the azurophil granules, human cathelicidin is present as propeptide in the specific granules and is cleaved after secretion to generate the antimicrobial peptide LL-37, a cationic 37 amino acid AMP bearing tandem N-terminal leucine residues. There is evidence that within the same organism cathelicidins are processed by different proteases in different physiological contexts: in humans, the activation of neutrophil-derived hCAP18/LL-37 is carried out by the serine protease proteinase 3 , whereas epididymal-derived hCAP18 in 
seminal plasma is cleaved by the prostate-derived protease gastricsin (pepsin C) in the presence of vaginal fluid at low $\mathrm{pH}$ (Zanetti, 2005). LL-37 has a stable $\alpha$-helical structure and kills bacteria by cell membrane disruption. Moreover, it binds LPS with high affinity, inhibiting LPS-induced cellular responses, and prevents macrophage activation by lipoteichoic acid and lipoarabinomannan (Scott et al., 2002). LL-37 also inhibits mycobacteria and induces a Toll-like receptor-mediated killing of $M$. tuberculosis by monocytes (MéndezSamperio, 2010). It has been shown that LL-37 is expressed by human epithelial cells in inflammatory environments such as wound healing, but it is also present in significant amounts in sweat, thus providing an innate anti-microbial defense system to the skin surface under non-inflammatory conditions (Murakami et al., 2002). LL-37 is constitutively expressed in gut epithelium and in lung alveolar macrophages and neutrophils. However, native LL-37 is hemolytic and toxic to human leukocytes. In vivo, LL-37 cytotoxic effects are inhibited by its binding to plasma proteins, but the binding also lowers antimicrobial efficacy (Ciornei et al., 2005). Considering LL-37 multifunctional activity, further investigation is needed to better define its biological properties and its possible therapeutic applications in the fields of immunomodulation and bacterial control. The future of cathelicidins relies on the ability to design synthetic more effective and less toxic variants (Mookherjee \& Hancock, 2007). Significant achievements in this field could be not too far, considering that a synthetic 13-amino acid peptide, IDR-1, conceptually based on LL-37, with no direct antimicrobial activity, protects against bacterial infections in vivo by inducing chemokine production and enhancing leukocyte recruitment (Scott et al., 2007). An IDR-1 derivative, IDR-1002, showed stronger protective activity in vitro and in mouse models of infection with S. aureus and E. coli (Nijnik et al., 2010). Another promising new molecule currently under investigation is novicidin, a linear cationic $\alpha$-helical AMP derived from ovispirin, a cationic peptide originated from the ovine cathelicidin SMAP-29 (Dorosz et al., 2010). A bovine cathelicidin with broad-spectrum activity, termed indolicidin, was originally isolated from bovine neutrophils (Selsted et al., 1992). Indolicidin is a 13-residue cationic peptide rich in tryptophan and proline, with a significant leishmanicidal activity, mediated by the disruption of L. donovani promastigotes and induction of autophagic cell death (Bera et al., 2003). It is also active against bacteria, fungi, and HIV, but its cytotoxicity prevents its use for therapeutic purposes (Rokitskaya et al., 2011). Less toxic derivatives such as omiganan (MBI-226), a 12-residue, indolicidin-based peptide variant, are currently under development (Rubinchik et al., 2009). This molecule, active on a wide range of bacteria and fungi, is currently undergoing confirmatory Phase III clinical trials for the prevention of infections arising from short-term central venous catheters, surgical contaminated wounds, and for the treatment of acne and rosacea (Rubinchik et al., 2009).

\subsection{Avian cathelicidins}

The genes of five cathelicidins termed fowlicidin-1, -2, -3, (Xiao et al., 2005), cathelicidin-B1 (Goitsuka et al., 2007), and myeloid antimicrobial peptide 27 (van Dijk et al., 2005), have been discovered by screening the chicken genome with bioinformatic methods. Functional analyses indicate that the corresponding synthesized peptides are among the most efficacious cathelicidins ever identified, with antibacterial and LPS-neutralizing activities that make them attractive candidates as antimicrobial and anti-sepsis agents. Fowlidicin-1, 2 and -3 , are highly active against both Gram-negative and Gram-positive bacteria including MRSA, even in the presence of salts, whilst many AMPs, as for example LL37, are inactivated by high salt concentrations. These features could be useful in the treatment of 
cystic fibrosis and Crohn's disease, both of which are related with aberrant local expression or inactivation of antimicrobial peptides (Saravanan \& Bhattacharjya, 2011). Starting from the consideration that fowlicidin- 1 is active against bacteria in the 1 to $2 \mu \mathrm{M}$ concentration range, has potent LPS-neutralizing activity, but is hemolytic and toxic to epithelial cells, a fowlicidin-1 analog denominated fowl-1(6-26), is currently being developed. It maintains the full-length peptide antibacterial and LPS-neutralizing efficacy, but following carboxylterminal amidation it is more stable in serum. The resulting peptide, fowl-1(6-26)-NH2, reduced bacterial titers in the peritoneal fluid and spleen and improved the survival of mice by $50 \%$ in MRSA-induced lethal infections, which makes it an excellent drug candidate against infections and sepsis induced by drug-resistant bacteria (Bommineni et al., 2010). In comparison with fowlicidin-1, fowlicidin-2 exhibits similar antibacterial efficacy but lower cell toxicity. To further reduce fowlicidin-2 toxicity several deletion analogs were designed and analyzed for their antibacterial, cytotoxic, membrane permeabilizing and LPSneutralizing activities. This work brought to the identification of 2 short peptide analogs, fowlicidin-2(1-18) and fowlicidin-2(15-31), which maintained the antibacterial and LPSneutralizing activities, but showed a significantly reduced cytotoxicity (Xiao et al., 2009).

\subsection{Snake cathelicidins}

Snake venoms are composed of active substances endowed with a wide array of neurotoxic, myotoxic, cardiotoxic, hemorrhagic, pro- and anticoagulant, antiparasitic and antibacterial effects. The whole venom of Bothrops marajoensis, a snake of the Viperidae family, as well as one of its purified components, i.e. L-amino acid oxidase, exhibits a strong inhibition on the growth of a wide range of microorganisms, such as S. aureus, C. albicans, P. aeruginosa, and Leishmania species (Costa Torres et al., 2009). The opportunities offered by the recent development of bioinformatic techniques have been exploited to identify the genes with AMP-related sequences expressed in venom gland tissues. Three cathelicidins from the elapid species Naja atra (Chinese cobra), Bungarus fasciatus (banded krait) and Ophiophagus hannah (king cobra) have been identified by molecular cloning (Zhao et al., 2008). Phylogenetic analysis suggests that snake cathelicidins are closely related to rodent neutrophilic granule proteins, avian fowlicidins and chicken myeloid antimicrobial peptide 27. Unlike the highly divergent mammalian cathelicidins, the nucleotide and deduced protein sequences of the three cloned elapid cathelicidins are remarkably conserved. Each of them has a 22 amino acid residue signal peptide, a conserved cathelin domain of 135 amino acids and a mature antimicrobial peptide of 34 amino acids. In order to explore the structure-function relationships relative to the bactericidal and hemolytic activities, king cobra cathelicidin (OH-CATH) has been used as a molecular template to develop shorter synthetic analogs. Among OH-CATH and its analogs, OH-CATH(5-34) has the lowest hemolytic activity but maintains a strong antimicrobial activity. To evaluate its potential clinic values, the biological activities of $\mathrm{OH}-\mathrm{CATH}(5-34)$ have been compared with those of pexiganan, a well-known phase III AMP derived from magainin. The bactericidal activity of OH-CATH(5-34) against 5 different species of bacteria (E. coli, P. aeruginosa, S. aureus, Enterobacter aerogenes and E. cloacae) was 2-4 times stronger than that of pexiganan. Hemolytic activity of $\mathrm{OH}-\mathrm{CATH}(5-34)$ against human erythrocytes was $0.69 \%$ while that of pexiganan was $16.5 \%$ at the dosage of $200 \mu \mathrm{g} / \mathrm{ml}$. The intravenous $\mathrm{LD}_{50}$ value of $\mathrm{OH}-$ CATH(5-34) on mice was 7-fold higher than that of pexiganan $(175 \mathrm{mg} / \mathrm{kg}$ vs $25 \mathrm{mg} / \mathrm{kg})$. Taken together, these results suggest that $\mathrm{OH}-\mathrm{CATH}(5-34)$ can be considered an excellent candidate for developing therapeutic drugs (Zhang et al., 2010). 


\section{Epithelial host defense peptides}

Healthy intact skin controls microbial growth by the combined action of complementary systems. The stratum corneum layer, with its lipid-rich matrix and protective low $\mathrm{pH}$, constitutes a physical and chemical barrier further supported by bacterial nutrient limitation and physical removal by desquamation. A wide array of bacteriostatic and bactericidal compounds belonging to the HDP family concurs to the prevention of skin infections by inhibiting potentially invading microorganisms and maintaining a balanced commensal flora on the skin. Once this biochemical barrier is disturbed, bacteria or bacterial factors have access to living epidermal keratinocytes and stimulate the innate immune response that goes under the name of inflammation (Meyer-Hoffert et al., 2011). In human skin HDPs are mainly produced by keratinocytes, neutrophils, sebocytes or sweat glands and are either expressed constitutively or following an inflammatory stimulus. The relevance of HDPs in the skin physiology and pathology is underlined by the fact that in several human skin diseases there is an inverse correlation between severity of the disease and the level of HDP production. Decreased HDP levels are associated with burns, chronic wounds, and atopic dermatitis. In contrast, in some cases HDP over-expression is believed to lead to increased protection against skin infections as seen in patients with psoriasis and rosacea, whose lesions rarely result in bacterial superinfection. In skin infections, such as acne vulgaris, increased levels of HDPs can be found in inflamed tissues, indicating a role of these peptides in the immune reaction to infection. The broad spectrum of antimicrobial activity, the low incidence of bacterial resistance and the immunomodulatory function are attractive features that suggest a high HDP potential as topical anti-infective drugs in several skin diseases (Schittek et al., 2008). The best studied among skin-related antibacterials are some members of the already treated defensin (hBD-1-3) and cathelicidin (LL-37) families, and a number of heterogeneous factors, such as psoriasin, dermcidin, RNase 7, and peptidoglycan recognition proteins.

\subsection{Psoriasin}

Psoriasin is a low molecular weight protein that owes its name to the fact of being intensely expressed by the keratinocytes of patients with psoriasis (Madsen et al., 1991). After cloning of the cDNA, the $11,457 \mathrm{kDa}$ protein was classified in the S100 protein family, that so far includes 21 low molecular weight $(9-13 \mathrm{kDa})$ calcium-binding proteins characterized by the solubility in $100 \%$ ammonium sulphate, from which is derived the name of the family. S100 proteins regulate many epithelial cell functions such as intracellular $\mathrm{Ca}^{2+}$ signaling, differentiation, cell-cycle progression, cytoskeletal membrane interactions, and leukocyte chemotaxis (McCormick \& Weinberg, 2010). Psoriasin antibacterial activity was discovered in 2005 (Glaser et al., 2005). The abundance of psoriasin on human skin together with its high antimicrobial activity against $E$. coli suggest that psoriasin may be an important factor in controlling E. coli growth on the skin surface. The physiological role of psoriasin in protecting the skin against $E$. coli colonization and infection has been confirmed by in vivo experiments with neutralizing antibodies. These experiments performed on the skin of various healthy people identified psoriasin as a principal E. coli-killing factor. Subsequent studies in cultured human keratinocytes identified flagellin, a Toll-like receptor-5 ligand, as the E. coli "pathogen-associated molecular pattern" responsible for the expression of psoriasin mRNA and protein. It has been observed that the production of psoriasin in 
human skin can also be induced by $P$. aeruginosa flagellin and rhamnolipids (Meyer-Hoffert et al., 2011). Indeed, P. aeruginosa is another ubiquitous bacterium that is however not usually present on healthy skin. These studies suggest that human skin might control the microflora to prevent colonization of the skin surface by unwanted microbes. Psoriasin is a metal ion-binding protein with a $\mathrm{Ca}^{2+}$ and $\mathrm{Zn}^{2+}$ binding capacity. Experiments aimed to clarify the mechanism of its antibacterial action demonstrated that in low concentrations $(0.5$ $\mu \mathrm{M})$ psoriasin kills $90 \%$ of all exposed E. coli. In higher doses $(>30 \mu \mathrm{M})$ psoriasin is bactericidal against $P$. aeruginosa and $S$. aureus, also. It seems that the mechanism of antibacterial action is mediated by zinc deprivation, zinc being an essential trace element for bacterial metabolism. Correspondingly, mutation experiments with recombinant psoriasin confirmed that zinc but not calcium binding is of significance for antibacterial activity (Glaser et al., 2005). Further, it was recently reported that psoriasin at pH values under 6 can also induce the formation of pores in the bacterial membrane (Glaser et al., 2011). The production by normal human keratinocytes of antimicrobial peptides, such as $\beta$-defensin- 2 and -3 , RNase 7, and psoriasin may be induced by ultraviolet radiation (Glaser et al., 2009). It is known that exposure to UV rays, especially of the B-waveband (UV-B, 280-315 nm), may suppress both systemic and local immune responses to a variety of antigens, and to several microorganisms (Termorshuizen et al., 2002). These findings suggest that UV-B irradiation suppresses T-cell-mediated immune responses but up-regulates the innate immune response by inducing the release of antimicrobial peptides.

\subsection{Dermcidin}

Dermcidin (DCD) is a human HDP isolated from sweat in 2001 (Schittek et al., 2001). It participates in the defense of the cutaneous surface, being constitutively secreted by eccrine sweat glands, but its expression has not been observed in epidermal keratinocytes of healthy skin, and it is not inducible by skin injury or inflammation. To date, DCD gene and mature peptide have been identified in humans only, and they show no homology to other known AMPs. Full length DCD consists of 110 amino acid residues with an N-terminal 19 amino acids signal peptide that is the hallmark of secreted proteins. In the sweat fluid, the DCD protein is cleaved by means of a post-secretory cathepsin D-mediated proteolytic process, giving rise to anionic and cationic peptides, two of which are recognized as the real effectors of the antimicrobial activity. A C-terminal 47 amino acid peptide corresponding to aa 63-109 of the originally translated product, named DCD-1, and a related peptide, DCD-1L, consisting of DCD-1 plus the last leucine (L) residue of the original precursor protein, have been identified in the sweat (Lai YP. et al., 2005). These peptides possess a potent and widespectrum antimicrobial activity against S. aureus, E. coli, Enterococcus faecalis, Listeria monocytogenes, Salmonellae, Pseudomonas and Candida albicans (Hata \& Gallo, 2008; Pathak et al., 2009). By means of nuclear magnetic resonance it has been established that DCD-1 has an $\alpha$-helical structure with a helix-hinge-helix motif, which is a common molecular fold among antimicrobial peptides (Jung et al., 2010). It seems that the affinity with which DCD-1 binds to bacterial-mimetic membranes is primarily dependent on its amphipathic $\alpha$-helical structure and its length (>30 residues), whereas its negative net charge and acidic isoelectric point have little effect on binding. These findings suggest that the DCD mode of action is similar to that of other membrane-targeting antimicrobial peptides, though the details of its antimicrobial action remain to be determined. Using immune electron microscopy, it has been shown that DCD-1 antimicrobial activity originates with its binding to the bacterial 
membrane, and that the molecule effectively kills S. epidermidis. DCD-1L shows stronger antimicrobial activity than the parent peptide, and it is highly effective against drugresistant $S$. aureus, as well as other Gram-positive and Gram-negative bacterial strains (Jung et al., 2010). The mechanisms by which DCD-derived peptides kill bacteria are still unclear. Bactericidal activity is time-dependent and induce bacterial membrane depolarization. However, these molecules do not induce pore formation in the membranes of Gramnegative and Gram-positive bacteria. Interestingly, LL-37, as well as DCD-derived peptides, inhibit bacterial macromolecular synthesis, especially RNA and protein synthesis, without binding to microbial DNA or RNA. Binding studies indicate that DCD-derived peptides bind to the bacterial envelope but show only a weak binding to lipopolysaccharide from Gram-negative bacteria or to peptidoglycan, lipoteichoic acid, and wall teichoic acid, isolated from S. aureus. In contrast, LL-37 binds strongly in a dose-dependent fashion to these components. These data indicate that the mode of action of DCD-derived peptides is different from that of the cathelicidin LL-37 and that components of the bacterial membranes play a role in the antimicrobial activity of DCD (Senyurek et al., 2009). Being a non-inducible factor, DCD contributes to the epithelial defense by modulating the surface colonization rather than by responding to injury and inflammation as is the case of the inducible peptides hBD-2 and -3, or LL-37 and psoriasin. Modulation and control of the skin-resident flora may be achieved by two types of effects: the non-specific prevention of microbial overgrowth on the skin surface, and the more specific prevention of skin colonization by pathogenic microorganisms, thereby establishing a host-friendly resident flora (Rieg et al., 2004). It appears that DCD could be the first of a new class of potential broad-spectrum antimicrobial drugs. In order to obtain large quantities of highly purified peptide for experimental use, it has been developed a method for the production of recombinant DCD-1L, in which it is expressed as a fusion protein, followed by enzymatic cleavage to release the active peptide. Recombinant DCD-1L is not cytotoxic against erythrocytes when assayed in PBS. This is supposed to be due to the presence of negatively charged sialic acid on the erythrocytes, that would electrostatically repel DCD-1L, which also has a net negative charge. This favorable condition suggests that it is of noteworthy potential as a therapeutic substance in clinical settings (Lai YP. et al., 2005).

\subsection{Ribonuclease 7}

RNase 7 was discovered as part of a broad screening protocol aimed at identifying antimicrobial agents in human skin (Harder \& Schroder, 2002). Successively, it has been discovered that it is also expressed by various epithelial tissues, especially in the respiratory and genitourinary tract. It is a highly cationic protein that shares a potent antibacterial activity with another member of the human RNase A superfamily, the eosinophil-derived RNase denominated ECP (eosinophil cationic protein/RNase 3). ECP possesses bactericidal, antiviral and antiparasitic activities and inhibits mammalian cell growth. Its ribonucleolytic activity with common RNA substrates is low and does not appear to be necessary for the antibacterial capacity. The finding that RNase 7 exhibited both antimicrobial and ribonuclease activity gave rise to the speculation that the enzymatic activity is involved in microbial killing. However, although the mechanisms involved in the antimicrobial properties of RNase 7 are not completely understood, its bactericidal activity has been linked to its capacity to permeate and disrupt the bacterial membrane, independent of its RNase activity (Spencer, 2011). RNase 7 is currently considered a major component of the 
antimicrobial protein and peptide group that constitutes the biochemical skin barrier (Boix \& Nogués, 2007), being active in the low micromolar concentration range against $S$. aureus, P. aeruginosa, Propionibacterium acnes, and C. albicans (Spencer, 2011). The hypothesis that RNase 7 may play an important role in the cutaneous antimicrobial defense system is further supported by the observation that contact of keratinocytes with bacteria induces RNase 7 gene expression, a finding that is in agreement with what is known for other epithelial antimicrobial proteins like the human defensins hBD-2, hBD-3, and hBD-4. Of particular interest is RNase 7 activity against vancomycin-resistant Enterococcus faecium. This potent antimicrobial activity supports the idea that RNase 7 might be a useful agent to treat the emerging infections caused by this and other multiresistant bacteria.

\subsection{Peptidoglycan recognition proteins}

The definition "peptidoglycan recognition protein"(PGRP) was first introduced in 1996 to indicate a $19 \mathrm{kDa}$ protein, present in the hemolymph and cuticle of a silkworm (Bombyx mori), that binds the peptidoglycan of Gram-positive bacteria and activates the prophenoloxidase cascade which generates melanin (Yoshida et al., 1996). Subsequently, many other similar molecules have been identified and added to the PGRP group, that includes conserved lectin-like proteins present in insects, mollusks, echinoderms, and vertebrates, but not in nematodes or plants. Mammals express a family of 4 PGRPs, which were initially named PGRP-S, PGRP-L, PGRP-I- $\alpha$ and PGRP-I- $\beta$ (for short, long and intermediate- $\alpha$ and $-\beta$ transcripts, respectively), analogous to insect PGRPs. These names were changed by the Human Genome Organization Gene Nomenclature Committee to PGLYRP-1, PGLYRP-2, PGLYRP-3, and PGLYRP-4, respectively. This terminology is also used for mouse PGRPs, and is now in use to selectively indicate vertebrate PGRPs. Both invertebrate and vertebrate PGRPs function as pattern recognition and effector molecules in innate immunity. All PGRP proteins have at least one C-terminal PGRP domain about 165 amino-acid residues long, that is homologous to the bacteriophage and bacterial type 2 amidases. This homology indicates that PGRPs and prokaryotic type 2 amidases might have evolved from a common primordial ancestor gene. Almost all PGRPs have two closely spaced, conserved Cys residues in the centre of the PGRP domain that form a disulphide bond, which is required for PGRP structural integrity and activity. Mammalian PGLYRPs are differentially expressed in various organs and tissues and perform both amidase and antibacterial activity. PGLYRP-1 is present in the granules of the polymorphonuclear leukocytes, and contributes to the killing of phagocytosed bacteria. PGLYRP-2, which is constitutively produced in the liver and secreted into the blood, is also induced in the skin and intestines. It is an $\mathrm{N}$-acetylmuramoyl-L-alanine amidase that hydrolyzes peptidoglycan reducing its proinflammatory activity. PGLYRP-3 has direct bactericidal activity and is expressed in the skin, eyes, tongue, esophagus, stomach, and intestines. PGLYRP-4 and the PGLYRP-3:4 dimer also have direct bactericidal activity in the same tissues; PGLYRP-4 is also expressed in the salivary gland, mucus-secreting glands in the throat and in saliva (Dziarski \& Gupta, 2006). It has been demonstrated that the bactericidal activity of human PGLYRP-1, PGLYRP-3, PGLYRP-4, and PGLYRP-3:4 against both Gram-positive and Gram-negative bacteria requires zinc (Wang M. et al., 2007). A previously unknown mechanism of bacterial killing by PGRPs has been recently elucidated by Kashyap et al., (2011). In Gram-positive bacteria, to perform their action PGRPs need to pass through the thick cell wall and bind 
peptidoglycan near the cell membrane. This can be accomplished only at the separation sites of newly formed daughter cells during cell division. The binding induces the activation of the bacterial CssR-CssS two-component system, which triggers bacterial killing by inducing membrane depolarization and the production of toxic $[\mathrm{OH}]^{\bullet}$ in the cytoplasm. This process is accompanied by the cessation of all major intracellular biosynthetic reactions, probably because of the lack of membrane potential-dependent generation of energy. Due to the different external structure of Gram-negative bacteria, in which a thin peptidoglycan layer is covered by a lipopolysaccharide-containing outer membrane, the initial interaction of PGRPs with Gram-negative bacteria is different. The analysis of the localization of PGRPs in E. coli by immunofluorescence and confocal microscopy demonstrated that the entire E. coli outer membrane uniformly binds PGRPs at all stages of growth, in contrast to the described selective localization of PGRPs to cell separation sites in Gram-positive bacteria. Following the binding to the outer membrane, the CpxA-CpxR two-component system, functionally homologous to the CssR-CssS system of Gram-positive bacteria, is activated. The CssR-CssS and CpxA-CpxR systems are designed to detect and dispose of extracellular misfolded bacterial proteins at the cell membrane-cell wall interface, after these proteins have been exported from the cell, and in Gram-negative bacteria CpxA-CpxR also detects proteins in the outer membrane. Notwithstanding the difference between the initial interaction mechanism, the killing mechanism of PGRPs seems common for all bacteria and depends on the activation of the protein-sensing two-component systems. These two-component systems can therefore be considered appealing targets for the development of new antibacterial therapies. PGRPs could be used as a basis for the design of shorter molecules that would maintain the broad-spectrum bactericidal activity of natural factors, but would be more convenient in terms of immunogenicity and production costs.

\section{Amphibian host defense peptides}

The skin of amphibia Anura (frogs and toads) is one of the richest reservoir of biologically active peptides. These HDPs are produced by dermal glands, stored within granules and released on the skin surface upon stress, injury, or electrical or norepinephrine stimulation. Their synthesis is induced by contact with microorganisms and is transcriptionally regulated by the NF-jB/IjBa machinery (Mangoni \& Shai, 2011). These peptides constitute a rich arsenal of broad-spectrum, cytolytic AMPs characterized by highly variable sequences (Vanhoye et al., 2003). It is estimated that there may be as many as $10^{5}$ different peptides produced by the known 5000 species of anuran amphibians, and more than 400 have been already identified from South American Hylidae or European, Asian or North American Ranidae amphibians (Nicolas \& El Amri, 2008). Therefore, the main work still concerns the screening and identification of the most useful factors. The structural characteristics of some amphibian peptides are interesting for their potential implications in the mechanism of antimicrobial activity. A class of structurally unique molecules, still in the characterization phase, contains an intermolecular disulphide bridge in the C-terminal portion of the peptide that creates a 7-9 residue macrocyclic region, sometimes referred to as the "Rana box". Many of these peptides originate from frogs belonging to the Rana genus and examples include esculentins, brevinins, ranacyclins, ranalexins, gaegurins, ranateurins and nigrocins (Haney et al., 2009). Here we focus on four families that include some of the better known and most representative peptides, namely magainins, dermaseptins, bombinins and temporins. 


\subsection{Magainins and magainin-related peptides}

Magainin-1 and -2 are the first AMPs isolated from the skin of the African clawed frog Xenopus laevis (Zasloff et al., 1987). Because they were among the first identified antimicrobial peptides, there has been considerable research associated with magainin structure and mechanism of action. Magainins are 23 amino acid peptides with $\alpha$-helical structure. Following the observation that magainin-2 possesses broad spectrum antibacterial and antifungal activity, many synthetic analogs have been developed in order to maximize the antimicrobial effects and minimize cytotoxicity. Magainin-A, a magainin-2 analog, underwent preclinical evaluation studies on Macaca radiata monkeys as local contraceptive, showing good spermicidal, antibacterial and antifungal activity (Clara et al., 2004), but has not been further developed. An extensive structure-activity investigation on magainin 2, performed by Zasloff and co-workers of Magainin Pharmaceuticals, resulted in the development of MSI-78 or pexiganan, a molecule that entered clinical trials for topical treatment of diabetic foot ulcers. In 1999 the FDA denied approval of pexiganan after completion of two phase III clinical trials, in which pexiganan resulted no more effective than already approved treatments for diabetic foot ulcers, and required addition clinical trials for consideration. Following successive acquisitions, pexiganan is by now being developed by Access Pharmaceuticals Inc. Improvements in clinical trial design, greater understanding of diabetic foot ulcers and topical anti-infective treatments, and advances in peptide manufacturing keep hopes alive regarding the potential FDA approval of pexiganan (Gottler \& Ramamoorthy, 2009).

A new peptide that is not a magainin, but is often included in the magainin family, is peptidyl-glycine-leucine-carboxyamide (PGLa), whose existence was predicted through the screening of a c-DNA library for clones encoding the precursor of caerulein (Hoffmann et al., 1983), when searching in amphibian skin secretions for peptides closely related to mammalian hormones and neurotransmitters. In this study it was concluded that this peptide could form a membrane-active amphipathic helix similar to peptides with bacteriostatic, cytotoxic and/or lytic properties. The natural PGLa counterpart was isolated two years later from the skin secretions of X. laevis by the same group (Andreu et al., 1985). At neutral $\mathrm{pH}$ this peptide has a positive net charge of 5 because of the four lysine residues and the amino group at the $\mathrm{N}$-terminal glycine. It also has an amidated C-terminus that provides good resistance to proteases (Lohner \& Prossnigg, 2009). PGLa showed good in vitro activity against E. coli, S. aureus, and S. pyogenes in the concentration range of 10-50 $\mu \mathrm{g} / \mathrm{ml}$, and was also active, but at higher concentrations, against $P$. aeruginosa (200-500 $\mu \mathrm{g} / \mathrm{ml})$, Saccharomyces cerevisiae $(100-200 \mu \mathrm{g} / \mathrm{ml})$, and C. albicans $(100-200 \mu \mathrm{g} / \mathrm{ml})$ (Soravia et al., 1988). PGLa activity has been also tested in vitro against Plasmodium falciparum, at a concentration range of $20-60 \mu \mathrm{M}$ (Boman et al., 1989). However, the peptide with the greatest potential for development into a therapeutically valuable anti-infective agent is by some considered the caerulein precursor fragment B1 (CPF-B1) (Mechkarska et al., 2010). Caerulein is a short peptide whose amino acid sequence shows a close resemblance to the mammalian gastrointestinal hormone gastrin. It was originally isolated from the skin of the Australian frog Hyla caerulea (De Caro et al., 1967). The structure of the caerulein precursor extracted from the X. laevis skin has been determined in 1985 (Wakabayashi et al., 1985). CPF-B1 is one of four CPF fragments (CPF-B1 -B4) that can be found in the skin secretions obtained from the norepinephrine-stimulated skin of the tetraploid frog Xenopus borealis (Pipidae). CPF-B1 is the most abundant fragment and is active against clinical isolates of the nosocomial pathogen MRSA and multidrug-resistant Acinetobacter baumannii with MIC 
values in the range $4-8 \mu \mathrm{M}$. It is also active against E. coli $(\mathrm{MIC}=5 \mu \mathrm{M})$ and $C$. albicans $(\mathrm{MIC}=25 \mu \mathrm{M})$, and shows low hemolytic activity on human erythrocytes. The high potency of CPF-B1 against MRSA and multidrug-resistant $A$. baumannii, together with its low toxicity suggest that the peptide could be used for the topical treatment of skin infections caused by these pathogens and in therapeutic regimes to promote wound healing (Mechkarska et al., 2010).

\subsection{Dermaseptins}

Dermaseptins are genetically related a-helical amphipathic AMPs 28-34 amino acid-long, with 3-6 lysine residues, and a highly conserved tryptophan residue in the third position from the C-terminus residue (Zairi et al., 2007). Dermaseptins are present in the skin of Hylidae and Ranidae frogs. They show a remarkable identity in the signal sequences of their preproforms, but have clearly diverged to yield several families of microbicidal cationic peptides that are structurally distinct (Amiche \& Galanth, 2011). Dermaseptin S1, the first member of the dermaseptin family to be discovered, was isolated from an extract of dried skin of Phyllomedusa sauvagei in the early 1990s (Mor et al., 1991). It was followed by the isolation of dermaseptin B2, also denominated adenoregulin for its ability to interact with the adenosine receptor, from the skin of the arboreal frog P. bicolor (Daly et al., 1992). Subsequently, dermaseptin B1, a 27-residue peptide, was also isolated from P. bicolor skin (Mor et al., 1994). These last 2 peptides were thought to be unrelated until attempts to clone their precursor polypeptides revealed the presence of a common preproregion and 5 '- and 3'-UTRs (Amiche et al., 1993). Since then, additional dermaseptins were rapidly identified in various South American species and now constitute the dermaseptin super-family. Basic research on dermaseptins is of relevance because genetic studies on the evolution and diversity of frog skin AMPs may lead to the identification of new peptides with alternative targets. In addition, the discovery of new isoforms with novel structural and biochemical properties may also shed light on the exact roles of various parameters, such as net charge, percent of $\alpha$-helical/ $\beta$-sheet structure, amphipathy and conformational flexibility, on the ability of antimicrobial peptides to bind to and disrupt bacterial membranes (Nicolas \& El Amri, 2008). Dermaseptin antimicrobial activity is currently being characterized and analogs are being developed. Dermaseptin S4 analogs are active against Neisseria gonorrhoeae (Zairi et al., 2007) and 15 analogs of dermaseptin S1, synthesized by our group, showed variable activity against Trichomonas vaginalis, Herpes simplex virus-1 and human Papillomavirus 16 (Savoia et al., 2008, 2010). These properties, coupled with the already demonstrated spermicidal activity of dermaseptins S, suggest that dermaseptins, as well as magainins, alone or even better in combination, could be used as topical contraceptives and microbicides to contemporarily prevent unwanted conceptions and sexually transmitted diseases.

\subsubsection{Plasticins}

Plasticins constitute a family of orthologous peptides with antimicrobial activity classified in the dermaseptin superfamily. They are quite similar as far as amino acid sequence, hydrophobicity, and amphipathicity are concerned, but differ markedly in their conformational plasticity and spectrum of activity (Vanhoye et al., 2003). The plasticins from phyllomedusid frogs of the Hylidae family may be divided into two classes on the basis of their cytolytic activities: the strongly cationic peptides plasticin-B1 (from P. bicolor) and -S1 (from P. sauvagei) that contain lysine residues and show potent, broad spectrum 
antimicrobial activity and hemolytic activity; and the weakly cationic or neutral plasticins (plasticin-A1, from Agalychnis annae, plasticin -C1 and -C2 from A. callidryas, and plasticinDA1 from Pachymedusa danicolor), that are hemolytic but devoid of antibacterial activity (Conlon et al., 2009). Plasticin-L1, more recently isolated from the South American frog Leptodactylus laticeps, falls into the second category and is devoid of cytolytic activity against Gram-positive and Gram-negative bacteria. However, in contrast to the other plasticins, it does not produce lysis of human erythrocytes at concentrations up to $500 \mu \mathrm{M}$ (Conlon et al., 2009). The plasticin peptide family constitutes a good model to address the relationships between structural polymorphism, membrane-interacting property, and biological activity of antimicrobial, cell-penetrating, and viral fusion peptides (El Amri \& Nicolas, 2008). Unlike amphipathic helical dermaseptins, plasticins display considerable conformational flexibility and polymorphism that modulate their ability to bind to and disrupt the bilayer membranes of prokaryotic and eukaryotic cells, and/or to reach intracellular targets (Nicolas \& El Amri, 2008).

\subsection{Bombinins and temporins}

In the 1960s, Csordas and Michl published a series of papers that culminated in 1970 with a report on the characterization of a hemolytic and antibacterial peptide 24 amino acid long, isolated from the European toad Bombina variegata (Csordás \& Michl, 1970). This peptide, called "bombinin," shares many of its general structural features with the larger group of magainins. A series of peptides from the skin of a closely related amphibian, Bombina orientalis (or Asian toad) has been subsequently isolated and characterized (Zangger et al., 2008). These peptides share considerable homology with bombinin and are called bombininlike peptides, or BLPs, and were found to possess potent antibacterial activities but, unlike bombinin, lack any appreciable hemolytic activity. Other peptides, structurally unrelated with previously discovered bombinins and containing a D-amino acid as the second residue, are the bombinins $\mathrm{H}$, endowed with both antibacterial and hemolytic properties (hence the final $-\mathrm{H}$ ) that were isolated from B. variegata skin (Mignogna et al. 1993). The expression of the genes encoding the common precursor for bombinins and bombinin $\mathrm{H}$ has been shown to be induced by bacterial infection in vivo as well as in vitro (Miele et al., 1998). Remarkably, after processing of the precursor, bombinin $\mathrm{H}$ is further modified by a recently characterized peptidyl-aminoacyl-L/D-isomerase that catalyses the inversion of the stereochemistry of the second amino terminal residue (Jilek et al., 2011; Zangger et al., 2008).

The first molecule belonging to the temporin family was identified in methanol extracts of the skin of the Asian frog Rana erythraea. In the early 1990s, Simmaco et al. identified a family of similar peptides with antibacterial and antifungal properties from the skin secretion of the European red frog Rana temporaria and termed them temporins (Mahalka et al., 2009; Simmaco et al., 1996). Subsequently, many other temporins have been isolated from the secretions of other ranid frogs of both North American and Euroasian origin. At present, the temporin family includes more than 100 members, which share a number of unique properties, such as: i) a short amino acid sequence, that favors cost-efficient chemical synthesis: most temporins are 10-14 amino acid long, with a few 16-17 amino acids exceptions, and an ultrashort temporin of only eight amino acid residues, that represents the smallest naturally occurring linear AMP so far identified, has been isolated from the skin of the frog Phelophylax saharica (Abbassi et al., 2010); ii) a low positive charge ranging from +2 to +3 at neutral $\mathrm{pH}$ (in contrast with most AMPs belonging to other families, which usually 
have a higher net positive charge); iii) high efficiency against a wide range of pathogens, that is retained in serum, and concomitant low or null toxicity to mammalian cells; iv) at least in some cases, immuno-modulatory and/or antiendotoxin activity (Mangoni \& Shai, 2011). Temporins exhibit antibacterial, antifungal, antiviral and antiprotozoan activities. Their potent action against Gram-positive bacteria, including methicillin-resistant strains, is of particular interest, because a synergistic action of the temporin A-methicillin association has been observed in a rat model of infection with methicillin-resistant S. epidermidis (Ghiselli et al., 2002). Temporin-1Tl has a higher and broader spectrum of activity than the other isoforms, being active against fungi and Gram-negative bacteria such as $P$. aeruginosa and E. coli, but it disrupts human erythrocytes at microbicidal concentrations (Mangoni et al., 2011). Temporins-1Ta, Tb, and Tl have been shown to neutralize the toxic effect of LPS derived from various species of E. coli, by complexing with it and making it unavailable for interaction with macrophage receptors to stimulate the production of TNF-a, considered a primary mediator of endotoxemia (Mangoni \& Shai, 2008). Owing to their characteristics, temporins are considered worth of further development. In this perspective, by studying the structure-activity relationship of a library of $\mathrm{Tl}$ derivatives, Mangoni and co-workers identified novel analogues with better properties that could be used for future developments (Mangoni et al., 2011).

\section{Insect host defense peptides: Defensins and cecropins}

Insects such as moths, flies and bees rely on a wide array of humoral peptidic factors to defend themselves against potential pathogens. A recently identified family of peptides isolated from the Apis mellifera royal jelly is represented by the jelleins. These are composed of 8-9 amino acids, are amidated at the $C$-terminus and bear a +2 charge (Romanelli et al., 2010). While these molecules are still in the characterization phase, the research on insect defensin went a little further. The core structure of invertebrate defensins is composed of an $\alpha$-helical domain linked to a two-stranded antiparallel $\beta$-sheet with three or four disulphide bonds forming the so-called cysteine-stabilized $\alpha$-helix $\beta$-sheet motif. Some antifungal peptides like drosomycin from Drosophila melanogaster contain an additional short Nterminal $\beta$-strand, so presenting a $\beta \alpha \beta \beta$-scaffold that is similar to that of antifungal plant defensins (Wilmes et al., 2011). Royalisin, an insect defensin isolated from the royal jelly of A. mellifera (Fujiwara et al., 1990), consists of 51 amino acids, in which six cysteine residues form three disulfide bonds that give the molecule a compact globular structure. Royalisin inhibits the growth of Gram-positive bacteria and fungi and is particularly active against the honeybee pathogen Paenibacillus larvae larvae, that causes American foulbrood, a serious disease found in honeybee larvae (Bilikova et al., 2001). Recombinant and functionally active royalisin has been recently obtained with a yield of the final purified product in the range of $0.192 \mathrm{mg} / \mathrm{L}$ of bacterial cell culture. Considering that the substance shows antibacterial activity at the $1-27 \mu \mathrm{g} / \mathrm{ml}$ concentration range, this breakthrough makes it possible to proceed to an extensive characterization of royalisin for both beekeeping and human therapeutic purposes (Tseng et al., 2011).

\subsection{Cecropins}

Cecropins are lytic peptides that possess antibacterial activity in vitro, originally isolated from the hemolymph of the giant silk moth Hyalophora cecropia (Hultmark et al., 1980). The 
killing is mediated by membrane permeabilization, with a detergent-like effect accompanied by pore formation (Bechinger \& Lohner, 2006). Cecropin specificity of action relies upon the differences in the composition and physicochemical properties of germ and host cell membranes. Pore formation is easily achieved in bacterial membranes rich in anionic phospholipids, but not in animal cell membranes, rich in neutral phospholipids and further stabilized by cholesterol. Cecropins are considered worth of further development because they show a well demonstrated biological activity and consist of a single polypeptide chain well suited for economical production through recombinant DNA technology or peptide synthesis. Cecropin-like peptides are currently being developed following different strategies to improve antimicrobial and anticancer activity and diminish cytotoxicity (Plunkett et al., 2009; Wu et al., 2009). Based on the assumption that lysozyme is inactive on Gram-negative bacteria because it cannot reach the peptidoglycan layer, and that cecropin may disrupt the outer membrane of Gramnegatives, giving the enzyme access to peptidoglycan, a novel hybrid protein combining Musca domestica cecropin with human lysozyme has been expressed in E. coli. This chimeric protein showed an improvement of antibacterial activity and spectrum compared to its single original components (Lu et al., 2010). Another chimera, the cecropin AD peptide, composed by the first 11 residues of $H$. cecropia cecropin A and the last 26 residues of $H$. cecropia cecropin D, has been produced in a Bacillus subtilis expression system (Chen X. et al., 2009). The potent antimicrobial activity against S. aureus and $E$. coli of the recombinant product, and the low cost of the production process, with a yield of $30.6 \mathrm{mg}$ of pure recombinant protein obtained from 1 liter of culture supernatant, make this molecule a suitable option for veterinary and medical applications. Cecropins have properties similar to those of melittin, a peptide that is the major component of the A. mellifera venom (Pandey et al., 2010). Some melittin analogues showed a drastic cytotoxicity reduction though maintaining comparable bactericidal activity. Two recombinant cecropin A- and cecropin B-melittin hybrid peptides $\mathrm{CA}(1-7)-\mathrm{M}(4-11)$ and $\mathrm{CB}(1-7)-\mathrm{M}(4-11)$ have been expressed in the yeast Pichia pastoris. Both chimeric peptides showed strong antibacterial activity against E. coli, S. aureus, P. aeruginosa, Klebsiella pneumoniae, Bacillus subtilis, B. thuringiensis, and Salmonella derby (Cao et al., 2010). The efficacy of a cecropin A-melittin hybrid peptide CA(1-8) $\mathrm{M}(1-18)$ and shorter derivatives against pan-resistant Acinetobacter baumannii has been tested both in vitro and in a mouse sepsis model. The peptide showed an in vitro good activity, that was not affected by the presence of capsule (Rodríguez-Hernández et al., 2006). However, in vivo the peptides showed bacteriostatic activity only, and $\mathrm{PD}_{50}$ was not achieved with non-toxic doses (López-Rojas et al., 2011). The antifungal and anti-inflammatory effects of a cecropin A(18)-magainin 2(1-12) hybrid peptide analog (P5) have been tested on Malassezia furfur and human keratinocytes. The minimal inhibitory concentration of P5 against M. furfur was $0.39 \mu \mathrm{M}$, making it 3-4 times more potent than commonly used antifungal agents such as ketoconazole $(1.5 \mu \mathrm{M})$ or itraconazole $(1.14 \mu \mathrm{M})$. P5 efficiently inhibited the expression of IL-8 and Toll-like receptor 2 in $M$. furfur-infected human keratinocytes without eukaryotic cytotoxicity at its fungicidal concentration. Moreover, P5 significantly down-regulated NF-kB activation and intracellular calcium fluctuation, which are closely related with enhanced responses of keratinocyte inflammation induced by $M$. furfur infection. Taken together, these observations suggest that P5 may be a potential therapeutic agent for $M$. furfur-associated human skin diseases because of its distinct antifungal and antiinflammatory action (Ryu et al., 2011). 


\section{Bacterial antimicrobial peptides}

A wide array of proteinaceous molecules is produced by Gram-positive and Gram-negative bacteria to counteract the proliferation of closely related microorganisms competing for limited resources within the same ecological niche (Héchard \& Sahl, 2002). The first description of antagonistic interactions between different Staphylococcus strains was made in 1855 by Babes, who with Cornil co-authored the first text on bacteriology. The same phenomenon was described by Pasteur, who noted the inhibitory effect of common bacteria from urine on Bacillus anthracis (Pasteur \& Joubert, 1877). However, the first clear documentation of an antibiotic agent produced by E. coli was provided by Gratia, who in 1925 demonstrated that in liquid media strain V (for virulence) produced a dialyzable and heat-stable substance (later referred to as colicin V) that even in high dilutions inhibited the growth of E. coli strain $\varphi$ (Gratia, 1925). Subsequently, a number of colicins produced by $E$. coli and closely related members of the Enterobacteriaceae were discovered. Following the discovery that antibiotic substances of the colicin type are also produced by non-coliform bacteria, the more general term "bacteriocin" was coined (Jacob et al., 1953), to define proteinaceous antibiotics of the colicin type, characterized by predominant intra-specific killing activity, and adsorption to specific receptors on the surface of sensitive cells (Jack et al., 1995; Tagg et al., 1976). Bacteriocins produced by Gram-positive bacteria differ in many characteristics from those produced by Gram-negative bacteria: the former are initially produced as propeptides, which are subsequently separated from a leader peptide to form the biologically active molecule. In some cases, such as the lantibiotics, post-translational modifications are introduced into the propeptide region of the precursor molecule prior to cleavage of the leader component (Cotter et al., 2005a). In contrast, Gram-negative bacteriocins (colicins) are generally high-molecular-mass (29- to 90-kDa) proteins that contain characteristic domains specifying either attachment specificity, translocation, or killing activity. Similar domain constructs have been found in some of the pyocins produced by $P$. aeruginosa (Jack et al., 1995).

\subsection{Gram-positive bacteriocins}

Although there is not a definitive classification for bacteriocins from Gram-positive bacteria, it is generally accepted the division into class I, composed by post-translationally modified peptides containing lanthionine or methyl-lanthionine; class II, or heat-stable nonlanthionine-containing bacteriocins, which are small thermostable, non-modified proteins (with the exception of disulfide bridges linkage), with or without leader peptide; and class III, which includes secreted heat-labile, cell wall-degrading enzymes. A family of circular, post-translationally modified bacteriocins has been recently grouped to form a new class of bacteriocins, class IV, that encompasses globular, thermostable, helical, and posttranslationally modified proteins, ranging between 35 and 70 amino acids, with the N- and C-termini linked by a peptide bond (Sanchez-Hidalgo et al., 2011).

\subsubsection{Class I bacteriocins: Lantibiotics}

Class I bacteriocins produced by lactic acid bacteria are the most widely investigated: they are small, heat-stable post-translationally modified peptides commonly called lantibiotics, that naturally occur in food and in the gastro-enteric tract of mammals. Some of them, such as nisin and lacticin, are widely used as antibacterial agents by the food and agricultural 
industry of more than 50 countries (Chatterjee et al., 2005; Cotter et al., 2005b). Lantibiotics are ribosomally synthesized as precursor peptides, and post-translationally modified by the dehydration of serine and threonine residues and subsequent intramolecular addition of cysteine, resulting in the formation of ( $\beta$-methyl) lanthionine thioether bridges, that characterizes the group (Abriouel et al., 2010). A N-terminal leader sequence is believed to keep the peptides inactive while inside the producing cell. To further protect themselves from the action of secreted lantibiotics, the lantibiotic-producing bacteria have evolved selfprotection mechanisms that consist of individual immunity proteins (generically termed the LanI proteins), or of highly conserved ATP-binding cassette transporter (ABC-transporter) proteins, usually composed of two or three subunits, generically termed LanFE(G) (Draper et al., 2008). Many lantibiotics are extremely potent antibacterial agents with minimum inhibitory concentrations in the nanomolar range (Ross \& Vederas, 2011). Lantibiotics are active against several very common food spoilage organisms (for example, Listeria monocytogenes and Clostridium botulinum) and show very promising activity against resistant S. aureus and enterococcal infections (Cotter et al., 2005a). In the last few years some bacteriocins have been considered for human health and medical purposes: nisin $\mathrm{A}$, the prototype lantibiotic produced by Lactococcus lactis, is highly efficient against Gram-positive bacteria and has no human toxicity. It was discovered in 1928 and has been accepted by the Food and Drug Administration as a food additive in 1988. Its 34-amino acid residue structure contains five macrocyclic rings stabilized by thioether bonds (Turpin et al., 2010). Nisin inhibits the growth of vegetative Gram-positive bacteria by binding to lipid II, so disrupting cell wall biosynthesis and facilitating pore formation. Nisin also inhibits the outgrowth of bacterial spores, including Bacillus anthracis spores (Gut et al., 2011). However, natural nisin A is unsuitable for medical uses, being unstable and poorly soluble in neutral or basic conditions and easily inactivated by thiols such as cysteine and glutathione (Rollema et al., 1995). Nisin A derivatives obtained by amino acid substitution are being developed and evaluated as anti-mycobacterial drugs (Carroll et al., 2010). Lacticin 3147, another lantibiotic produced by lactic acid bacteria, is more stable than nisin and is active against MRSA and VRE at nanomolar concentrations (Piper et a., 2009). Lacticin 3147 consists of a 2-peptide (lacticin A1 and A2) system: lacticin A1 binds lipid II, and the complex binds lacticin A2, that induces pore formation in the bacterial membrane. To the class I bacteriocins also belongs thuricin $\mathrm{CD}$, another 2-component peptide system produced by Bacillus thuringiensis and selectively active against Clostridium difficile. A problem inherent the current antibiotic treatment of $C$. difficile-associated bowel disease is that large-spectrum antibiotics can perturb the gut flora to the point to interfere with recovery and in same cases even to promote recurrences. These problems could be avoided by the use of thuricin CD that, according to extensive tests against a broad range of Gram-positive and Gram-negative bacteria, targets a restricted spectrum of spore-forming Gram-positive bacteria (Rea et al., 2010).

\subsubsection{Class II bacteriocins}

Class II bacteriocins include class IIa one-peptide pediocin-like bacteriocins and class-IIb, that are two-peptide bacteriocins (Nissen-Meyer et al., 2010). Pediocin PA-1 is a representative member of the class IIa bacteriocins, i.e. low molecular weight, plasmidencoded peptides, with marked antilisterial activity, produced by Pediococcus acidilactici 
(Devi \& Halami, 2011). It is currently investigated as a useful tool to control Listeria monocytogenes in food (Hartmann et al., 2011). At least 15 two-peptide members of the class$\mathrm{IIb}$ bacteriocins have been isolated and characterized since the first isolation of lactococcin $\mathrm{G}$ (Nissen-Meyer et al., 1992). Like lacticins, these bacteriocins consist of two different peptides, and optimal antibacterial activity requires the presence of both peptides in about equal amounts. The two peptides are synthesized as preforms that contain a 15-30 residue $\mathrm{N}$-terminal leader sequence that apparently facilitates interaction with the dedicated ABCtransporter membrane protein and might possibly also function to keep the bacteriocin inactive until it has been secreted. The genes encoding the preforms of the two peptides are always found next to each other in the same operon along with the gene that encodes the immunity protein. Class IIb bacteriocins are still in the characterization phase, in order to develop variants useful for medical and biotechnological applications, such as infection treatment and food and animal feed preservation (Nissen-Meyer et al., 2010). Class III bacteriocins, like enterolysin A, are large antibacterial proteins with enzymatic activity (Nilsen et al., 2003), that for their structure are not considered suitable for drug development. On the contrary, low-molecular weight, circular class IV bacteriocins possess some interesting features: the joining of the ends protects from degradation by exopeptidase enzymes, increasing stability and making the molecules highly resistant to a wide range of $\mathrm{pH}$ and temperatures. A representative member of class IV bacteriocins is AS- 48 , that is the first reported circular bacteriocin and whose structure and genetic regulation have been elucidated. It can be considered a good starting point to develop analogs with new and/or improved features for practical chemical, pharmaceutical and agricultural applications. (Sanchez-Hidalgo et al., 2011).

\subsection{Gram-negative bacteriocins}

Enterobacteria can secrete colicins and microcins, both encoded by gene clusters that codify for their production, export and self-immunity. To date, all colicins and microcins found are plasmid-encoded, except class IIb microcins, that are chromosome-encoded. Colicin gene clusters are highly conserved, but simpler than microcin gene clusters. In contrast to microcins, the production of colicins is mainly induced via the DNA repair network, called the SOS response, that can be activated by an environmental stress, such as UV irradiation, exposure to DNA damaging agents, or cell starvation. The major differences between microcins and colicins, besides the molecular mass, lie in their structure and in the fact that contrary to most microcins, colicins are not post-translationally modified.

\subsubsection{Colicins}

Colicins are large proteins organized in three functional domains: a central receptor binding domain, an N-terminal translocation domain and a C-terminal catalytic domain. These domains, which are common to all colicins, ensure every common step of the colicin mechanisms of action, i.e. i) recognition by a specific receptor at the outer membrane, ii) translocation across the outer membrane and iii) lethal interaction with a specific cellular target. The ability of an E. coli strain to kill neighboring strains by releasing colicins into the surroundings has been known since the 1920s (Gratia, 1925). However, the mechanism by which colicins reach the target cell cytoplasm, crossing the outer membrane, the peptidoglycan layer and the inner membrane, has only recently begun to be unraveled at the molecular level. It seems that the penetration mechanism is similar, even though different 
colicins parasitize different protein systems and kill cells by different mechanisms (Cascales et al., 2007). Colicins are not considered for development into suitable antibacterial drugs, mainly because of their high molecular weight, but their study has significantly contributed to the progress of basic research in a number of fields, such as the bacterial outer membrane protein receptors, and the proteins of the translocation machinery.

\subsubsection{Microcins}

The name microcin was introduced to distinguish the class of antibacterial peptides with molecular mass below $10 \mathrm{kDa}$, from the higher molecular mass colicins (Asensio et al., 1976). Whereas many antimicrobial peptides of bacterial origin are produced by large multidomain enzyme complexes termed peptide synthetases, microcins are typically produced as ribosomally synthesized precursors, similar to the bacteriocins from Gram-positive bacteria. Microcins are encoded by plasmid- or chromosome-located gene clusters, which typically include open reading frames encoding the microcin precursor, self-immunity factors, secretion proteins and modification enzymes, giving rise to an amazing diversity of microcin structures and mechanisms of action (Duquesne et al., 2007). Microcins are secreted by enterobacteria (mostly E. coli) under conditions of nutrient depletion, and are involved in the regulation of microbial competition within the intestinal microbiota. They are generally hydrophobic, highly resistant to heat, extreme $\mathrm{pH}$ and proteases, and exert potent antibacterial activity in nanomolar concentrations, usually against a narrow spectrum of closely related species. Their mechanism of action has been defined as a "Trojan horse" behavior: they are recognized as siderophores by the outer membrane receptors of susceptible bacteria, and as such internalized; once inside they bind essential enzymes or interact with the inner membrane killing the bacterium (Duquesne et al., 2007). At present microcins are still into the characterization phase, and despite their potent antibacterial activity, they are not being developed as antibacterials (Corsini et al., 2010). Microcin E492, a pore-forming molecule produced by Klebsiella pneumoniae, beyond exerting antibacterial activity on related strains, has been shown to induce apoptosis of malignant human cell lines (Lagos et al., 2009). Microcin B17, produced by various E. coli strains harboring the 70$\mathrm{kb}$ single-copy, conjugative pMccB17 plasmid, is a potent inhibitor of DNA gyrase, whereas microcin J25, the best-studied member of the lasso peptides, inhibits RNA polymerase (Oman \& van der Donk, 2010).

\section{Lipopeptides and lipoglycopeptides}

Antimicrobial lipopeptides (LiPs) are non-ribosomally produced by bacteria and fungi during cultivation on various carbon sources. They are a class of antibiotics highly active against multidrug-resistant bacteria. Most native LiPs consist of a short (six to seven amino acids) linear or cyclic peptide sequence, either positively or negatively charged, with a fatty acid moiety covalently attached to the N-terminus. (Mangoni \& Shai, 2011). Both the composition of the peptide moiety and the type of the lipophilic part are sensitive to modifications. In general, native LiPs are non-cell-selective and therefore quite toxic to mammalian cells. Despite toxicity, in 2003 a member of this family, daptomycin, which is active only toward Gram-positive bacteria, has been approved by the FDA in an injection formulation for the treatment of complicated skin and skin structure infections (SSSI) caused by susceptible strains of the following species: S. aureus (including methicillin-resistant 
strains), Streptococcus pyogenes, S. agalactiae, S. dysgalactiae subspecies equisimilis, and Enterococcus faecalis (vancomycin-susceptible strains only). This example confirms the growing opinion that peptide-based antibiotics will be among the next generation of antiinfective therapy (Mangoni \& Shai, 2011). Dalbavancin, oritavancin and telavancin are semisynthetic lipoglycopeptides active against multidrug-resistant Gram-positive pathogens (Zhanel et al., 2010). These molecules share a heptapeptide core that affects cell wall synthesis by inhibiting transglycosilation and transpeptidation, and contain lipophilic side chains that facilitate binding to cell membranes and increase antibacterial activity. Lipophilic residues also prolong in vivo half life, that is of 147-258 h for dalbavancin, of $393 \mathrm{~h}$ for oritavancin and of 12-24 h for telavancin. These drugs must be administered i.v. and are indicated for patients with complicated SSSI resistant to vancomycin. Telavancin has been approved for SSSI therapy by the FDA in September 2009. Dalbavancin, a teicoplanin derivative, has a long half life that allows for once weekly dosing. In published clinical trials, a dose on day 1 and 8 of treatment provided 14 days of antimicrobial activity, and demonstrated non-inferiority as measured by safety and efficacy for the treatment of uncomplicated SSSI, catheter-related bloodstream infections, and complicated SSSI (Welte \& Pletz, 2010).

\section{Bacteriophage endolysins}

Since the pioneer work of d'Herelle, several studies demonstrated that bacteriophages can be successfully used in the therapy of animal and human bacterial infections (Harper \& Enright, 2011; Verma et al., 2009). Phages are already used in the agricultural, foodprocessing and fishery industries, and for the treatment of human bacterial infections in Georgia and Eastern Europe (Housby \& Mann, 2009). Recent experiments performed by Fu et al. on the efficacy of a bacteriophage cocktail to prevent the formation of $P$. aeruginosa biofilms on catheters in an in vitro model showed a $99.9 \%$ reduction of the number of bacteria (Fu et al., 2010). The human use of phages in Western countries has been hindered so far by cost, safety concerns about phage injection into the bloodstream, and by the sometimes inconsistent outcome of the treatments, due to the poor characterization of bacteriophage preparations. Moreover, the in vivo pharmacokinetics of phages are complex, being influenced by the host immune system-mediated phage clearance rate and by the possible insurgence of bacterial resistance due to lysogeny or mutations concerning metabolic steps or surface receptors (Payne \&Jansen, 2003). However, phage therapy is considered a potential treatment for some selected infections, such as multidrug resistant $P$. aeruginosa lung infection in cystic fibrosis patients (Morello et al., 2011), and chronic otitis (Wright et al., 2009). A different approach overcoming some of the above-mentioned problems involves the use of purified phage products as anti-infective agents. Doublestranded DNA phages naturally produce endolysins, i.e. mureine-degrading enzymes, that have been originally studied and developed to control mucous membrane infections (Borysowski et al., 2006), and are also denominated "enzybiotics" (Briers et al., 2011). They only work on Gram-positive bacteria because the outer membrane of Gram-negative bacteria prevents direct lysin-peptidoglycan interaction (Fischetti, 2010). To this end, the paper from Briers et al. reports that the use of endolysins in conjunction with outer membrane permeabilizers resulted in strong lytic activity against $P$. aeruginosa, with a reduction of more than four log units of viable bacteria in $30 \mathrm{~min}$. Endolysins, some of which have been found active against B. anthracis (Schuch et al., 2002), S. pneumoniae (Jado et 
al., 2003) and S. agalactiae (Cheng et al., 2005), alone or in combination with conventional antibiotics or lysozyme, have a short half-life $(15-20 \mathrm{~min})$, but their action is so rapid that nanogram quantities kill sensitive Gram-positive bacteria in seconds after contact (Loeffler et al., 2001). Moreover, they are per se non toxic and, unexpectedly, not easily inactivated by antibodies (Fischetti, 2008). Considering that the endolysin target, peptidoglycan, is not present in eukaryotic cells, it can be anticipated that they will also be well tolerated by humans. Experiments performed on a murine model of pneumococcal pneumonia showed that an endolysin with muramidase activity, Cpl-1, protected $100 \%$ of mice when administered by intraperitoneal injections starting 24 hours after pulmonary infection (Witzenrath et al., 2009). These results suggest that Cpl-1 and related molecules could provide a new therapeutic option for pneumococcal pneumonia. The issue of the possible toxic effect due to the massive release of pro-inflammatory molecules by lysed bacteria has also been addressed. Circulating endotoxin, teichoic and lipoteichoic acids, and peptidoglycan could result in septic shock and multiple organ failure, but so far no sideeffects related to lysin-induced bacteriolysis have been reported (Borysowski et al., 2006). According to experiments performed on a murine model, lysins may also cure already established infections (Witzenrath et al., 2009). More predictable endolysin applications include the elimination of bacteria from mucous membranes, the treatment of bacterial infections, and the biocontrol of bacteria in food.

\section{Conclusions}

Modern antibiotics are or derive from natural molecules isolated during the "golden age" of antibiotic discovery, i.e. the period between the1940s and the 1970s. Even those currently under development are nothing more than new, improved versions of these old natural products, because the chemical modification of existing molecules remains the most costefficient way to develop novel drugs active against resistant strains. As examples, we can cite the cephalosporin ceftaroline (Corey et al., 2010), the tetracycline amadacycline (PTK0796), the streptogramin NXL-103 (Politano \& Sawyer, 2010) and the macrolide CEM101 (Woosley et al., 2010). However, the perspective that these agents, new but based on old molecular scaffolds, will in their turn face the development of bacterial resistance, prompted both the academic community and the biotech/pharmaceutical companies to look for alternative strategies. In this scenario, the low molecular weight, broad-spectrum activity and rapid mode of action of AMPs make them promising drug candidates. Among potential advantages of some AMPs we can add the endotoxin-neutralizing ability and the capacity to modulate the host immune response. Moreover, they are usually unaffected by classic antibiotic resistance mechanisms (Zasloff, 2002). In this regard, however, concerns have been raised by the finding that some microorganisms are able to thwart AMP effects: $C$. albicans is sensitive to histatin-5, the most potent antifungal peptide present in human saliva (Edgerton \& Koshlukova, 2000), but it produces aspartyl proteases that target this molecule, and in the presence of low histatin levels, as those occurring in AIDS patients, the yeast turns from a harmless commensal to a disease-causing pathogen (Meiller et al., 2009). Moreover, taking for granted that acquired resistance to AMPs is less likely to occur as compared to the traditional antibiotics, it has been observed that some Gram-negative bacteria can utilize various enzymes to reduce their surface net negative charge, so evading the action of cationic peptides (Roy et al., 2009). Several other bacterial strategies have been described that can result in decreased susceptibility to AMPs, such as secretion of 
inactivating proteins or exportation via efflux pumps. Therefore, the onset of resistance in microbial populations consistently exposed to AMPs cannot be excluded (Peters et al., 2010), and a theoretical concern about the pharmacological use of AMPs closely related to human ones is that long term selection could generate organisms with unpredictable virulence potential (Fernebro, 2011). In addition to these (for now) theoretical concerns, we must recognize that some more practical AMP flaws, such as the high production cost and the susceptibility to proteolytic degradation, have until now effectively prevented AMPs from entering the market. Most AMPs today in preclinical and clinical trials have been developed for topical applications (Hancock \& Sahl, 2006). Examples of indications are catheter site infections, cystic fibrosis, acne and wound healing. For complicated wounds and ulcers caused by multidrug-resistant bacteria, phage therapy, although the available literature is in many ways unsatisfactory, could be an option. In the EU, it has been proposed that specific sections concerning phage therapy should be included in the Advanced Therapy Medicinal Product Regulation to make it easier to get approval for clinical trials involving such therapy (Verbeken et al., 2007). For practical and economical reasons it could be easier to market purified lysins for which, so far, resistance development has not been observed. However, most lysins are endowed with short in vivo half-life (Loeffler et al., 2003), an issue that has to be solved before they enter clinical use. Another relevant issue is the possibility to use narrow spectrum AMPs, such as microcins. Conceptually, a broad spectrum antibiotic is not always the best choice, especially when considering its effects on the commensal flora and the risk of inducing opportunistic infections. However, the use of narrow spectrum antibiotics should be supported by diagnostics faster and more accurate than those in use today. The development of new antimicrobials is a formidable challenge, and out of this concern, in 2009 the U.S. and European Community presidencies established a Transatlantic Task Force, and the Infectious Diseases Society of America called for a global commitment to develop 10 novel antimicrobials by 2020 (Gwinn et al., 2010). In our view, the achievement of badly needed good results relies on a balanced interaction between well funded academic laboratories and the lead discovery departments of private companies, to make the most of existent and future techniques.

\section{References}

Abbassi, F., Lequin, O., Piesse, C., Goasdoué, N., Foulon, T., Nicolas, P., \& Ladram, A. (2010). Temporin-SHf, a new type of phe-rich and hydrophobic ultrashort antimicrobial peptide. The Journal of Biological Chemistry, Vol.285, No. 22, (May 28), pp. 16880-16892, ISSN 0021-9258

Abriouel, H., Franz, CM., Ben Omar, N., \& Gálvez, A. (2011). Diversity and applications of Bacillus bacteriocins. FEMS Microbiology Reviews, Vol. 35, No. 1, pp. 201-232, ISSN 0168-6445

Amiche, M., Ducancel, F., Lajeunesse, E., Boulain, JC., Ménez, A., \& Nicolas, P. (1993). Molecular cloning of a cDNA encoding the precursor of adenoregulin from frog skin. Relationships with the vertebrate defensive peptides, dermaseptins. Biochemical and Biophysical Research Communications, Vol. 191, No. 3, (Mar 31), pp. 983-990, ISSN 0006-291X 
Amiche, M., \& Galanth, C. (2011). Dermaseptins as models for the elucidation of membraneacting helical amphipathic antimicrobial peptides. Current pharmaceutical biotechnology, Vol. 12, No. 8, (Aug 1), pp. 1184-1193, ISSN 1389-2010

Andreu, D., Aschauer, H., Kreil, G., \& Merrifield, RB. (1985). Solid-phase synthesis of PYLa and isolation of its natural counterpart, PGLa [PYLa-(4-24)] from skin secretion of Xenopus laevis. European Journal of Biochemistry, Vol. 149, pp. 531-535, ISSN 00142956

Asensio, C., \& Pérez-Díaz, JC. (1976). A new family of low molecular weight antibiotics from enterobacteria. Biochemical and Biophysical Research Communications, Vol. 69, No. 1, (Mar 8), pp. 7-14, ISSN 0006-291X

Baltz, RH. (2008). Renaissance in antibacterial discovery from actinomycetes. Current Opinion in Pharmacology, Vol. 8, No. 5, pp. 557-63, ISSN 1471-4892

Bechinger, B., \& Lohner, K. (2006). Detergent-like actions of linear amphipathic cationic antimicrobial peptides. Biochimica et Biophysica Acta, Vol. 1758, No. 9, 1529-1539, ISSN 0006-3002

Bera, A., Singh, S., Nagaraj, R., \& Vaidya, T. (2003). Induction of autophagic cell death in Leishmania donovani by antimicrobial peptides. Molecular and Biochemical Parasitology, Vol. 127, No. 1, pp. 23-35, ISSN 0166-6851

B1likova, K., Gusui, W., \& Simuth, J. (2001). Isolation of a peptide fraction from honeybee royal jelly as a potential antifoulbrood factor. Apidologie, Vol. 32, pp. 275-283, ISSN 0044-8435

Boix, E., \& Nogués, MV. (2007). Mammalian antimicrobial proteins and peptides: overview on the RNase A superfamily members involved in innate host defence. Molecular BioSystems, Vol. 3, No. 5, pp. 317-335, ISSN 1742-206X

Bommineni, YR., Dai, H., Gong, YX., Soulages, JL., Fernando, SC., Desilva, U., Prakash, O., \& Zhang, G. (2007). Fowlicidin-3 is an alpha-helical cationic host defense peptide with potent antibacterial and lipopolysaccharide-neutralizing activities. FEBS Journal, Vol. 274, No. 2, pp. 418-428, ISSN 1432-1033

Borysowski, J., Weber-Dabrowska, B., \& Górski, A. (2006). Bacteriophage endolysins as a novel class of antibacterial agents. Experimental Biology and Medicine (Maywood), Vol. 231, No. 4, pp. 366-377, ISSN 1535-3702

Briers, Y., Walmagh, M., \& Lavigne, R. (2011). Use of bacteriophage endolysin EL188 and outer membrane permeabilizers against Pseudomonas aeruginosa. Journal of Applied Microbiology, Vol. 110, No. 3, pp. 778-785, ISSN 1364-5072

Brinch, KS., Tulkens, PM., Van Bambeke, F., Frimodt-Møller, N., Høiby, N., \& Kristensen, HH. (2010). Intracellular activity of the peptide antibiotic NZ2114: studies with Staphylococcus aureus and human THP-1 monocytes, and comparison with daptomycin and vancomycin. Journal of Antimicrobial Chemotherapy, Vol. 65, No. 8, pp. 1720-1724, ISSN 0305-7453

Bulet, P., Stöcklin, R., \& Menin, L. (2004). Anti-microbial peptides: from invertebrates to vertebrates. Immunology Reviews, Vol. 198, pp.169-184, ISSN 0105-2896

Cao, Y., Yu, RQ., Liu, Y., Zhou, HX., Song, LL., Cao, Y., \& Qiao, DR. (2010). Design, recombinant expression, and antibacterial activity of the cecropins-melittin hybrid antimicrobial peptides. Current Microbiology, Vol. 61, No. 3, pp. 169-175, ISSN 03438651 
Carroll, J., Field, D., O'Connor, PM., Cotter, PD., Coffey, A., Hill, C., Ross, RP., \& O'Mahony, J. (2010). Gene encoded antimicrobial peptides, a template for the design of novel anti-mycobacterial drugs. Bioengineered Bugs, Vol 1, No. 6, pp. 408-412, ISSN 19491018

Cascales, E., Buchanan, SK., Duché, D., Kleanthous, C., Lloubès, R., Postle, K., Riley, M., Slatin, S., \& Cavard, D. (2007). Colicin biology. Microbiology and Molecular Biology Reviews, Vol. 71, No. 1, pp. 158-229, ISSN 0005-3678

Chatterjee, C., Paul, M., Xie, L., \& van der Donk, WA. (2005). Biosynthesis and mode of action of lantibiotics. Chemical Reviews, Vol. 105, No. 2, pp. 633-684, ISSN 0009-2665

Chen, H., Xu, Z., Peng, L., Fang, X., Yin, X., Xu, N., \& Cen, P. (2006). Recent advances in the research and development of human defensins. Peptides, Vol. 27, No. 4, pp. 931-940, ISSN 0196-9781

Chen, X.,; Zhu, F., Cao, Y., \& Qiao, S. (2009). Novel expression vector for secretion of cecropin AD in Bacillus subtilis with enhanced antimicrobial activity. Antimicrobial Agents and Chemotherapy, Vol. 53, No. 9, pp. 3683-3689, ISSN 0066-4804

Cheng, Q., Nelson, D., Zhu, S., \& Fischetti, VA. (2005). Removal of group B streptococci colonizing the vagina and oropharynx of mice with a bacteriophage lytic enzyme. Antimicrobial Agents and Chemotherapy, Vol. 49, No. 1, pp. 111-117, ISSN 0066-4804

Chin, JN., Rybak, MJ., Cheung, CM., \& Savage, PB. (2007). Antimicrobial activities of ceragenins against clinical isolates of resistant Staphylococcus aureus. Antimicrobial Agents and Chemotherapy, Vol. 51, pp. 1268-1273, ISSN 0066-4804

Chopra, I. (1993). The magainins: antimicrobial peptides with potential for topical application. The Journal of Antimicrobial Chemotherapy, Vol. 32, No. 3, pp. 351-353, ISSN 0305-7453

Ciornei, CD., Sigurdardóttir, T., Schmidtchen, A., \& Bodelsson, M. (2005). Antimicrobial and chemoattractant activity, lipopolysaccharide neutralization, cytotoxicity, and inhibition by serum of analogs of human cathelicidin LL-37. Antimicrobial Agents and Chemotherapy, Vol. 49, No. 7, pp. 2845-2850, ISSN 0066-4804

Clara, A., Manjramkar, DD., \& Reddy, VK. (2004). Preclinical evaluation of magainin-A as a contraceptive antimicrobial agent. Fertility and Sterility, Vol. 81, No. 5, pp. 13571365, ISSN 0015-0282.

Cole, AM., \& Waring, AJ. (2002). The role of defensins in lung biology and therapy. American Journal of Respiratory and Critical Care Medicine, Vol. 1, No. 4, pp. 249-59, ISSN 1073449X

Conlon, JM., Abdel-Wahab, YH., Flatt, PR., Leprince, J., Vaudry, H., Jouenne , T., \& Condamine, E. (2009). A glycine-leucine-rich peptide structurally related to the plasticins from skin secretions of the frog Leptodactylus laticeps (Leptodactylidae). Peptides, Vol. 30, No. 5, pp. 888-892, ISSN: 0196-9781

Corey, GR., Wilcox, M., Talbot, GH., Friedland, HD., Baculik, T., Witherell, GW., Critchley, I., Das, AF., \& Thye, D. (2010). Integrated Analysis of CANVAS 1 and 2: Phase 3, Multicenter, Randomized, Double-Blind Studies to Evaluate the Safety and Efficacy of Ceftaroline versus Vancomycin plus Aztreonam in Complicated Skin and SkinStructure Infection. Clinical Infectious Diseases, Vol. 51, pp. 641-650, ISSN 1058-4838

Corsini, G., Karahanian, E., Tello, M., Fernandez, K., Rivero, D., Saavedra, JM., \& Ferrer, A. (2010). Purification and characterization of the antimicrobial peptide microcin N. FEMS Microbiology Letters, Vol. 312, No. 2, pp.119-125, ISSN 0378-1097 
Costa Torres, AF., Dantas, RT., Toyama, MH., Diz Filho, E., Zara, FJ., Rodrigues de Queiroz, MG., Pinto Nogueira, NA., Rosa de Oliveira, M., de Oliveira Toyama, D., Monteiro, HS., \& Martins, AM. (2010). Antibacterial and antiparasitic effects of Bothrops marajoensis venom and its fractions: Phospholipase A2 and L-amino acid oxidase. Toxicon, Vol. 55, No. 4, (Apr 1), pp. 795-804, ISSN 0041-0101

Cotter, PD., Hill, C., \& Ross, RP. (2005a). Bacterial lantibiotics: strategies to improve therapeutic potential. Current Protein \& Peptide Science, Vol. 6, No. 1, pp. 61-75, ISSN 1389-2037

Cotter, PD., Hill, C., \& Ross, RP. (2005b) Bacteriocins: developing innate immunity for food. Nature Reviews Microbiology, Vol. 3, No. 10, pp. 777-788, ISSN 1740-1526

Csordás, A., \& Michl H. (1970). Isolation and structure of a haemolytic polypeptide from the defensive secretion of European Bombina species. Monatshefte fur Chemie. Vol. 101, pp. 182-189, ISSN 1434-4475

Daly, JW., Caceres, J., Moni, RW., Gusovsky, F., Moos, M. Jr., Seamon, KB., Milton, K., \& Myers, CW. (1992). Frog secretions and hunting magic in the upper Amazon: identification of a peptide that interacts with an adenosine receptor. Proceedings of the National Academy of Sciences USA, Vol. 89, No. 22, (Nov 15), pp. 10960-10963, ISSN 0027-8424

Davies, J. (2011). How to discover new antibiotics: harvesting the parvome. Current Opinion in Chemical Biology, Vol. 15, No. 1, pp. 5-10, ISSN 1367-5931

De Caro, G., Endean, R., Erspamer, V., \& Roseghini, M. (1968). Occurrence of caerulein in extracts of the skin of Hyla caerulea and other Australian hylids. British Journal of Pharmacology and Chemotherapy, Vol. 33, No. 1, pp. 48-58, ISSN 0366-0826

Devi, SM., \& Halami, PM. (2011). Detection and Characterization of Pediocin PA-1/AcH like Bacteriocin Producing Lactic Acid Bacteria. Current Microbiology, Vol. 63, No. 2, pp. 181-185, ISSN 0343-8651

Dorosz, J., Gofman, Y., Kolusheva, S., Otzen, D., Ben-Tal, N., Nielsen, NC., \& Jelinek, R. (2010). Membrane interactions of novicidin, a novel antimicrobial peptide: phosphatidylglycerol promotes bilayer insertion. The Journal of Physical Chemistry B, Vol. 114, No. 34, pp. 11053-11060, ISSN 1089-5647

Draper, LA., Ross, RP., Hill, C., \& Cotter, PD. (2008). Lantibiotic immunity. Current Protein $\mathcal{E}$ Peptide Science, Vol. 9, No. 1, pp. 39-49, ISSN 1389-2037

Duquesne, S., Petit, V., Peduzzi, J., \& Rebuffat, S. (2007). Structural and functional diversity of microcins, gene-encoded antibacterial peptides from enterobacteria. Journal of Molecular Microbiology and Biotechnology, Vol. 13, No. 4, pp. 200-209, ISSN 1464-1801

Dziarski, R., \& Gupta, D. (2006). The peptidoglycan recognition proteins (PGRPs). Genome Biology, Vol. 7, No. 8, p. 232, ISSN 1465-6906

Edgerton, M., \& Koshlukova, SE. (2000). Salivary histatin 5 and its similarities to the other antimicrobial proteins in human saliva. Advances in Dental Research, Vol. 14, pp. 1621, ISSN 0895-9374

El Amri, C., \& Nicolas, P. (2008). Plasticins: membrane-damaging peptides with 'chameleonlike' properties. Cellular and Molecular Life Sciences, Vol. 65, No. 6, pp. 895-909, ISSN 1420-682X

Fernebro, J. (2011). Fighting bacterial infections-future treatment options. Drug Resistance Updates, Vol. 14, No. 2, pp. 125-139, ISSN 1368-7646 
Finlay, BB., \& Hancock, RE. (2004). Can innate immunity be enhanced to treat microbial infections? Nature Reviews Microbiology, Vol. 2, No. 6, pp. 497-504, ISSN 1740-1526

Fischbach, MA., \& Walsh, CT. (2009). Antibiotics for emerging pathogens. Science, Vol. 325, No. 5944, pp. 1089-1093, ISSN 0036-8075

Fischetti, VA. (2008). Bacteriophage lysins as effective antibacterials. Current Opinion in Microbiology, Vol. 11, No. 5, pp. 393-400, ISSN 1369-5274

Fischetti, VA. (2010). Bacteriophage endolysins: a novel anti-infective to control Grampositive pathogens. International Journal of Medical Microbiology, Vol. 300, No. 6, 357362, ISSN 1438-4221

Fu, W., Forster, T., Mayer, O., Curtin, JJ., Lehman, SM., \& Donlan, RM. (2010). Bacteriophage cocktail for the prevention of biofilm formation by Pseudomonas aeruginosa on catheters in an in vitro model system. Antimicrobial Agents and Chemotherapy, Vol. 54, No. 1, pp. 397-404, ISSN 0066-4804

Fujiwara, S., Imai, J., Fujiwara, M., Yaeshima, T., Kawashima, T., \& Kobayashi, K. (1990). A potent antibacterial protein in royal jelly. The Journal of Biological Chemistry, Vol. 265, pp. 11333-11337, ISSN 0021-9258

Gabriel, GJ., \& Tew, GN. (2008). Conformationally rigid proteomimetics: a case study in designing antimicrobial aryl oligomers. Organic and Biomolecular Chemistry, Vol. 6, No. 3, pp. 417-423, ISSN 1477-0520

Ganz, T., Selsted, ME., \& Lehrer, RI. (1986). Antimicrobial activity of phagocyte granule proteins. Seminars in Respiratory Infections, Vol. 1, No. 2, pp. 107-117, ISSN 0882-0546

Ghiselli, R., Giacometti, A., Cirioni, O., Mocchegiani, F., Orlando, F., Kamysz, W., Del Prete, MS., Lukasiak, J., Scalise, G., \& Saba, V. (2002). Temporin A as a prophylactic agent against methicillin sodium-susceptible and methicillin sodium-resistant Staphylococcus epidermidis vascular graft infection. Journal of Vascular Surgery, Vol. 36, No. 5, pp. 1027-1030, ISSN 0741-5214

Gläser, R., Harder, J., Lange, H., Bartels, J., Christophers, E., \& Schröder, JM. (2005). Antimicrobial psoriasin (S100A7) protects human skin from Escherichia coli infection. Nature Immunology, Vol. 6, No. 1, pp. 57-64, ISSN 1529-2908

Gläser, R., Navid, F., Schuller, W., Jantschitsch, C., Harder, J., Schröder, JM., Schwarz, A., \& Schwarz, T. (2009). UV-B radiation induces the expression of antimicrobial peptides in human keratinocytes in vitro and in vivo. Journal of Allergy and Clinical Immunology, Vol. 123, pp. 1117-1123, ISSN 0091-6749

Gläser, R. (2011). Research in practice: Antimicrobial peptides of the skin. Journal der Deutschen Dermatologischen Gesellschaft. May 25. doi: 10.1111/j.16100387.2011.07708.x. [Epub ahead of print], ISSN 1610-0379

Goitsuka, R., Chen, CL., Benyon, L., Asano, Y., Kitamura, D., \& Cooper, MD. (2007). Chicken cathelicidin-B1, an antimicrobial guardian at the mucosal $\mathrm{M}$ cell gateway. Proceedings of the National Academy of Sciences USA, Vol. 104, No. 38, (Sep 18), pp. 15063-15068, ISSN 0027-8424

Gottler, LM., \& Ramamoorthy, A. (2009). Structure, membrane orientation, mechanism, and function of pexiganan--a highly potent antimicrobial peptide designed from magainin. Biochimica et Biophysica Acta, Vol. 1788, No. 8, pp. 1680-1686, ISSN 00063002 
Gratia, A. (1925). Sur un remarquable exemple d'antagonisme entre deux souches de colibacille. Comptes Rendus des Séances et Mémoires de la Société de Biologie, Vol. 93, pp. 1040-1041, ISSN 0037-9026

Gut, IM., Blanke, SR., \& van der Donk, WA. (2011). Mechanism of Inhibition of Bacillus anthracis Spore Outgrowth by the Lantibiotic Nisin. ACS Chemical Biology, E pub. April 26, ISSN 1554-8929

Gwynn, MN., Portnoy, A., Rittenhouse, SF., \& Payne, DJ. (2010). Challenges of antibacterial discovery revisited. Annals of the New York Academy of Sciences, Vol. 1213, pp. 5-19, ISSN 0077-8923

Hancock, RE., \& Sahl, HG. (2006). Antimicrobial and host-defense peptides as new antiinfective therapeutic strategies. Nature Biotechnology, Vol. 24, No. 12, pp. 1551-1557, ISSN 1087-0156

Haney, EF., Hunter, HN., Matsuzaki, K., \& Vogel, HJ. (2009). Solution NMR studies of amphibian antimicrobial peptides: linking structure to function? Biochimica et Biophysica Acta, Vol. 1788, No. 8. pp. 1639-1655, ISSN 0006-3002

Harder, J., \& Schroder, JM. (2002). RNase 7, a novel innate immune defense antimicrobial protein of healthy human skin. The Journal of Biological Chemistry, Vol. 277, No. 48, (Nov 29), pp. 46779-46784, ISSN 0021-9258

Harper, DR., \& Enright, MC. (2011). Bacteriophages for the treatment of Pseudomonas aeruginosa infections. Journal of Applied Microbiology, Mar 16 Epub ahead of print. Online ISSN 1365-2672

Harris, F., Dennison, SR., \& Phoenix, DA. (2009). Anionic antimicrobial peptides from eukaryotic organisms. Current Protein E Peptide Science, Vol. 10, No. 6, pp. 585-606, ISSN 1389-2037

Hartmann, HA., Wilke, T., \& Erdmann, R. (2011). Efficacy of bacteriocin-containing cell-free culture supernatants from lactic acid bacteria to control Listeria monocytogenes in food. International Journal of Food Microbiology, Vol. 146, No. 2, (Mar 30), pp. 192-199, ISSN 0168-1605

Hata, TR., \& Gallo, RL. (2008). Antimicrobial peptides, skin infections, and atopic dermatitis. Seminars in Cutaneous Medicine and Surgery, Vol. 27, No. 2, pp. 144-150, ISSN 10855629

Héchard, Y., \& Sahl, HG. (2002). Mode of action of modified and unmodified bacteriocins from Gram-positive bacteria. Biochimie, Vol. 84, No. 5-6, pp. 545-557, ISSN 03009084

Hoffmann, W., Richter, K., \& Kreil, G. (1983). A novel peptide designated PYLa and its precursor as predicted from cloned mRNA of Xenopus laevis skin. EMBO Journal, Vol. 2, pp. 711-714, ISSN 0261-4189

Hölzl, MA., Hofer, J., Steinberger, P., Pfistershammer, K., \& Zlabinger, GJ. (2008). Host antimicrobial proteins as endogenous immunomodulators. Immunology Letters, Vol. 119, No. 1-2, pp. 4-11, ISSN 0165-2478

Housby, JN., \& Mann, NH. (2009). Phage therapy. Drug Discovery Today, Vol. 14, No. 11-12, pp. 536-540, ISSN 1359-6446

Hultmark, D., Steiner, H., Rasmuson, T., \& Boman, HG. (1980). Insect immunity. Purification and properties of three inducible bactericidal proteins from hemolymph of immunized pupae of Hyalophora cecropia. European Journal of Biochemistry, Vol. 106, No. 1, pp. 7-16, ISSN 0014-2956 
Jack, RW., Tagg, JR., \& Ray, B. (1995). Bacteriocins of gram-positive bacteria. Microbiological Reviews. Vol. 59, No. 2, pp. 171-200, ISSN 0146-0749

Jacob, F., Lwoff, A., Siminovitch, A., \& Wollman, E. (1953). Definition de quelques termes relatifs a la lysogenie. Annales de l'Institut Pasteur, Vol. 84, pp. 222-224, ISSN 09244204

Jado, I., López, R., García, E., Fenoll, A., Casal, J., \& García, P. (2003). Spanish Pneumococcal Infection Study Network. Phage lytic enzymes as therapy for antibiotic-resistant Streptococcus pneumoniae infection in a murine sepsis model. Journal of Antimicrobial Chemotherapy, Vol. 52, No. 6, pp. 967-973, ISSN 0305-7453

Jilek, A., Mollay, C., Lohner, K., \& Kreil, G. (2011). Substrate specificity of a peptidylaminoacyl-L: /D: -isomerase from frog skin. Amino Acids, Mar 22. Epub ahead of print, ISSN 0939-4451

Jung, HH., Yang, ST., Sim, JY., Lee, S., Lee, JY., Kim, HH., Shin, SY, \& Kim, JI. (2010). Analysis of the solution structure of the human antibiotic peptide dermcidin and its interaction with phospholipid vesicles. Biochemistry and Molecular Biology Reports, Vol. 43, No. 5, pp. 362-368, ISSN 1976-6696

Kashyap, DR., Wang, M., Liu, LH., Boons, GJ., Gupta, D., \& Dziarski, R. (2011). Peptidoglycan recognition proteins kill bacteria by activating protein-sensing twocomponent systems. Nature Medicine, Vol. 17, No. 6, pp. 676-683, ISSN 1078-8956

Kougias, P., Chai, H., Lin, PH., Yao, Q., Lumsden, AB., \& Chen, C. (2005). Defensins and cathelicidins: neutrophil peptides with roles in inflammation, hyperlipidemia and atherosclerosis. Journal of Cellular and Molecular Medicine, Vol. 9, No. 1, pp. 3-10, ISSN 1582-1838

Lagos, R., Tello, M., Mercado, G., García, V., \& Monasterio, O. (2009). Antibacterial and antitumorigenic properties of microcin E492, a pore-forming bacteriocin. Current Pharmaceutical Biotechnology, Vol. 10, No. 1, pp. 74-85, ISSN 1389-2010

Lai, XZ., Feng, Y., Pollard, J., Chin, JN., Rybak, MJ., Bucki, R., Epand, RF., Epand, RM., \& Savage, PB. (2008). Ceragenins: cholic acid-based mimics of antimicrobial peptides. Accounts of Chemical Research, Vol. 41, No. 10, pp. 1233-1240, ISSN 0001-4842

Lai, YP., Peng, YF., Zuo, Y., Li, J., Huang, J., Wang, LF., \& Wu, ZR. (2005). Functional and structural characterization of recombinant dermcidin-1L, a human antimicrobial peptide. Biochemical and Biophysical Research Communications, Vol. 328, No. 1, (Mar 4), pp. 243-250, ISSN 0006-291X

Lee, SB., Li, B., Jin, S., \& Daniell, H. (2011). Expression and characterization of antimicrobial peptides Retrocyclin-101 and Protegrin-1 in chloroplasts to control viral and bacterial infections. Plant Biotechnology Journal, Vol. 9, No. 1, pp. 100-115, ISSN 18635466

Liang, QL., Zhou, K., \& He, HX. (2010). Retrocyclin 2: a new therapy against avian influenza H5N1 virus in vivo and vitro. Biotechnology Letters, Vol. 32, No. 3, pp. 387-392, ISSN 0141-5492

Loeffler, JM., Nelson, D., \& Fischetti, VA. (2001). Rapid killing of Streptococcus pneumoniae with a bacteriophage cell wall hydrolase. Science, Vol. 294, No. 5549, pp. 2170-2172, ISSN 0036-8075

Loeffler, JM., Djurkovic, S., Fischetti, VA. (2003). Phage lytic enzyme Cpl-1 as a novel antimicrobial for pneumococcal bacteremia. Infection and Immunity, Vol. 71, pp. 6199-6204, ISSN 0019-9567 
Lohner, K, \& Prossnigg, F. (2009). Biological activity and structural aspects of PGLa interaction with membrane mimetic systems. Biochimica et Biophysica Acta, Vol. 788, No. 8, pp. 1656-1666, ISSN 0006-3002

López-Rojas, R., Docobo-Pérez, F., Pachón-Ibáñez, ME., de la Torre, BG., Fernández-Reyes, M., March, C., Bengoechea, JA., Andreu, D., Rivas, L., \& Pachón, J. (2011). Efficacy of cecropin A-melittin peptides on a sepsis model of infection by pan-resistant Acinetobacter baumannii. European Journal of Clinical Microbiology and Infectious Diseases, Apr 12. Epub ahead of print, ISSN 0934-9723

Lu, XM., Jin, XB., Zhu, JY., Mei, H,F., Ma, Y., Chu, FJ., Wang, Y., \& Li, XB. (2010). Expression of the antimicrobial peptide cecropin fused with human lysozyme in Escherichia coli. Applied Microbiology and Biotechnology, Vol. 87, No. 6, pp. 2169-2176, ISSN 01757598

Madsen, P., Rasmussen, HH., Leffers, H., Honore, B., Dejgaard, K., Olsen, E., Kiil, J., Walbum, E., Andersen, AH., Basse, B., Lauridsen, JB., Ratz, GP., Celis, A., Vandekerckhove, J., \& Celis, JE. (1991). Molecular cloning, occurrence, and expression of a novel partially secreted protein "psoriasin" that is highly upregulated in psoriatic skin. Journal of Investigative Dermatology, Vol. 97, pp. 701-712, ISSN 0022-202X

Mahalka, AK., \& Kinnunen, PK. (2009). Binding of amphipathic alpha-helical antimicrobial peptides to lipid membranes: lessons from temporins B and L. Biochimica et Biophysica Acta, Vol. 1788, No. 8, pp. 1600-1609, ISSN 0006-3002

Mangoni, ML., \& Shai, Y. (2009). Temporins and their synergism against Gram-negative bacteria and in lipopolysaccharide detoxification. Biochimica et Biophysica Acta, Vol. 1788, No. 8, pp. 1610-1619, ISSN 0006-3002

Mangoni, ML., \& Shai, Y. (2011). Short native antimicrobial peptides and engineered ultrashort lipopeptides: similarities and differences in cell specificities and modes of action. Cellular and Molecular Life Sciences, Vol. 68, No. 13, pp. 2267-2280, ISSN $1420-682 X$

Mangoni, ML., Carotenuto, A., Auriemma, L., Saviello, MR., Campiglia, P., GomezMonterrey, I., Malfi, S., Marcellini, L., Barra, D., Novellino, E., \& Grieco, P. (2011). Structure-activity relationship, conformational and biological studies of temporin L analogues. Journal of Medicinal Chemistry, Vol. 54, No. 5, pp. 1298-1307, ISSN 00222623

Maróti, G., Kereszt, A., Kondorosi, E., \& Mergaert, P. (2011). Natural roles of antimicrobial peptides in microbes, plants and animals. Research in Microbiology, Vol. 162, No. 4, pp. 363-374, ISSN 0923-2508

McCormick, TS., \& Weinberg, A. (2010). Epithelial cell-derived antimicrobial peptides are multifunctional agents that bridge innate and adaptive immunity. Periodontology 2000, Vol. 54, No. 1, pp. 195-206, ISSN 0906-6713

Mechkarska, M., Ahmed, E., Coquet, L., Leprince, J., Jouenne, T., Vaudry, H., King, JD., \& Conlon, JM. (2010). Antimicrobial peptides with therapeutic potential from skin secretions of the Marsabit clawed frog Xenopus borealis (Pipidae). Comparative biochemistry and physiology. Toxicology \& pharmacology, Vol. 152, No. 4, pp. 467-472, ISSN 1532-0456

Meiller, TF., Hube, B., Schild, L., Shirtliff, ME., Scheper, MA., Winkler R, Ton., A, \& JabraRizk, MA. (2009). A novel immune evasion strategy of Candida albicans: proteolytic 
cleavage of a salivary antimicrobial peptide. PLoS One, Vol. 4, No. 4, e5039, ISSN 1932-6203

Méndez-Samperio, P. (2010). The human cathelicidin hCAP18/LL-37: a multifunctional peptide involved in mycobacterial infections. Peptides, Vol. 31, No. 9, pp. 1791-1798, ISSN 0196-9781

Meyer-Hoffert, U., Zimmermann, A., Czapp, M., Bartels, J., Koblyakova, Y., Gläser, R., Schröder, JM., \& Gerstel, U. (2011). Flagellin delivery by Pseudomonas aeruginosa rhamnolipids induces the antimicrobial protein psoriasin in human skin. PLoS One, Vol. 6, No. 1, e16433, ISSN 1932-6203

Miele, R., Ponti, D., Boman, HG., Barra, D., \& Simmaco, M. (1998). Molecular cloning of a bombinin gene from Bombina orientalis: detection of NF-kappaB and NF-IL6 binding sites in its promoter. FEBS Letters, Vol. 431, No. 1, (Jul 10), pp. 23-28, ISSN 00145793

Mignogna, G., Simmaco, M., Kreil, G., \& Barra, D. (1993). Antibacterial and haemolytic peptides containing D-alloisoleucine from the skin of Bombina variegata. EMBO Journal, Vol. 12, No. 12, pp. 4829-4832, ISSN 0261-4189

Mookherjee, N., \& Hancock, RE. (2007). Cationic host defence peptides: innate immune regulatory peptides as a novel approach for treating infections. Cellular and Molecular Life Sciences, Vol. 64, No. 7-8, pp. 922-933, ISSN 1420-682X

Mor, A., Nguyen, VH., Delfour, A., Migliore-Samour, D., Nicolas, P. (1991). Isolation, amino acid sequence, and synthesis of dermaseptin, a novel antimicrobial peptide of amphibian skin. Biochemistry, Vol. 30; No. 36, (Sep 10), pp. 8824-8830, ISSN 00062960

Mor, A., Hani, K., \& Nicolas, P. (1994). The vertebrate peptide antibiotics dermaseptins have overlapping structural features but target specific microorganisms. The Journal of Biological Chemistry, Vol. 269, No. 50, (Dec 16), pp. 31635-31641, ISSN 0021-9258

Moreira, CK., Rodrigues, FG., Ghosh, A., Varotti, Fde P., Mirando, A., Daffare, S., JacobsLorena, M., \& Moreira, LA. (2007). Effect of the antimicrobial peptide gomesin against different life stages of Plasmodium spp. Experimental Parasitology, Vol. 116, No. 4, pp. 346-353, ISSN 0014-4894

Morello, E., Saussereau, E., Maura, D., Huerre, M., Touqui, L., \& Debarbieux, L. (2011). Pulmonary bacteriophage therapy on Pseudomonas aeruginosa cystic fibrosis strains: first steps towards treatment and prevention. PLoS One, Vol. 6, No. 2, e16963, ISSN 1932-6203

Murakami, M., Ohtake, T., Dorschner, RA., Schittek, B., Garbe, C., \& Gallo, RL. (2002). Cathelicidin anti-microbial peptide expression in sweat, an innate defense system for the skin. Journal of Investigative Dermatology, Vol. 119, No. 5, pp. 1090-1095, ISSN 0022-202X

Mygind, PH., Fischer, RL., Schnorr, KM., Hansen, MT., Sönksen, CP., Ludvigsen, S., Raventós, D., Buskov, S., Christensen, B., De Maria, L., Taboureau, O.,, Yaver, D., Elvig-Jørgensen, SG., Sørensen, MV., Christensen, BE., Kjaerulff, S., FrimodtMoller, N., Lehrer, RI., Zasloff, M., \& Kristensen, HH. (2005). Plectasin is a peptide antibiotic with therapeutic potential from a saprophytic fungus. Nature, Vol. 437, pp. 975-980, ISSN 0028-0836

Nakamura, T., Furunaka, H., Miyata, T., Tokunaga, F., Muta, T., Iwanaga, S., Niwa, M., Takao, T., \& Shimonishi, Y. (1988). Tachyplesin, a class of antimicrobial peptide 
from the hemocytes of the horseshoe crab (Tachypleus tridentatus). Isolation and chemical structure. The Journal of Biological Chemistry, Vol. 263, No. 32, (Nov 15), pp. 16709-11673, ISSN 0021-9258

Nicolas, P., \& El Amri, C. (2009). The dermaseptin superfamily: a gene-based combinatorial library of antimicrobial peptides. Biochimica et Biophysica Acta, Vol. 1788, No. 8, pp. 1537-1550, ISSN 0006-3002

Nijnik, A., Madera, L., Ma, S., Waldbrook, M., Elliott, MR., Easton, DM., Mayer, ML., Mullaly, SC., Kindrachuk, J., Jenssen, H., \& Hancock, R.E. (2010). Synthetic cationic peptide IDR-1002 provides protection against bacterial infections through chemokine induction and enhanced leukocyte recruitment. The Journal of Immunology, Vol. 184, No. 5, pp. 2539-2550, ISSN 0022-1767

Nilsen, T., Nes, IF., \& Holo, H. (2003). Enterolysin A, a cell wall-degrading bacteriocin from Enterococcus faecalis LMG 2333. Applied and Environmental Microbiology, Vol. 69, No. 5, pp. 2975-2984, ISSN 0099-2240

Nissen-Meyer, J., Holo, H., Håvarstein, LS., Sletten, K., Nes, IF. (1992). A novel lactococcal bacteriocin whose activity depends on the complementary action of two peptides. The Journal of Bacteriology, Vol. 174, No. 17, pp. 5686-5692, ISSN 0021-9193

Nissen-Meyer, J., Oppegård, C., Rogne, P., Haugen, HS., Kristiansen, PE. (2010). Structure and Mode-of-Action of the Two-Peptide (Class-IIb) Bacteriocins. Probiotics and Antimicrobial Proteins, Vol. 2, No. 1, pp. 52-60, ISSN 1867-1306

Oman, T.J., \& van der Donk, WA. (2010). Follow the leader: the use of leader peptides to guide natural product biosynthesis. Nature Chemical Biology, Vol. 6, No. 1, pp. 9-18, ISSN 1552-4450

Pandey, BK., Ahmad, A., Asthana, N., Azmi, S., Srivastava, RM., Srivastava, S., Verma, R., Vishwakarma, AL., \& Ghosh, JK. (2010). Cell-selective lysis by novel analogues of melittin against human red blood cells and Escherichia coli. Biochemistry, Vol. 49, No. 36, pp. 7920-7929, ISSN 0006-2960

Pasteur, L., \& Joubert, JF. (1877). Charbon et septicemie. Comptes Rendus des Séances et Mémoires de la Société de Biologie, Vol. 85, pp. 101-115, ISSN 0037-9026

Pathak, S., De Souza, GA., Salte, T., Wiker, HG., \& Asjö, B. (2009). HIV induces both a downregulation of IRAK-4 that impairs TLR signalling and an up-regulation of the antibiotic peptide dermcidin in monocytic cells. Scandinavian Journal of Immunology, Vol. 70, No. 3, pp. 264-276, ISSN 0300-9475

Payne, RJ., \& Jansen, VA. (2003). Pharmacokinetic principles of bacteriophage therapy. Clinical Pharmacokinetics, Vol. 42, No. 4, pp. 315-325, ISSN 0312-5963

Payne, DJ., Gwynn, MN., Holmes, DJ., \& Pompliano DL. (2007). Drugs for bad bugs: confronting the challenges of antibacterial discovery. Nature Review of Drug Discovery, Vol. 6, No. 1, pp. 29-40, ISSN 1474-1776

Penberthy, WT., Chari, S., Cole, AL., \& Cole, AM. (2011). Retrocyclins and their activity against HIV-1. Cellular and Molecular Life Sciences, Vol. 68, No. 13, pp. 2231-2242, ISSN 1420-682X

Peters, BM., Shirtliff, ME., \& Jabra-Rizk, MA. (2010). Antimicrobial peptides: primeval molecules or future drugs? PLoS Pathogens, Vol. 6, No. 10 (Oct 28), e1001067, ISSN 1553-7374

Piper, C., Draper, LA., Cotter, PD., Ross, RP., \& Hill, C. (2009). A comparison of the activities of lacticin 3147 and nisin against drug-resistant Staphylococcus aureus and 
Enterococcus species. Journal of Antimicrobial Chemotherapy, Vol. 64, No. 3, pp. 546551, ISSN 0305-7453

Plunkett, RM., Murray, SI., \& Lowenberger, CA. (2009). Generation and characterization of the antibacterial activity of a novel hybrid antimicrobial peptide comprising functional domains from different insect cecropins. Canadian Journal of Microbiology, Vol. 55, No. 5, pp. 520-528, ISSN 0008-4166

Politano, AD., \& Sawyer, RG. (2010). NXL-103, a combination of flopristin and linopristin, for the potential treatment of bacterial infections including community-acquired pneumonia and MRSA. Current Opinion in Investigational Drugs, Vol. 11, pp. 225236, ISSN 1472-4472

Ramasundara, M., Leach, ST., Lemberg, DA., \& Day, AS. (2009). Defensins and inflammation: the role of defensins in inflammatory bowel disease. Journal of Gastroenterology and Hepatology, Vol. 24, No. 2, pp. 202-208, ISSN 0815-9319

Rea, MC., Sit, CS., Clayton, E., O'Connor, PM., Whittal, RM., Zheng, J., Vederas, JC., Ross, RP., \& Hill, C. (2010). Thuricin CD, a posttranslationally modified bacteriocin with a narrow spectrum of activity against Clostridium difficile. Proceedings of the National Academy of Sciences U S A, Vol. 107, No. 20, pp. 9352-9357, ISSN 0027-8424

Rieg, S., Garbe, C., Sauer, B., Kalbacher, H., \& Schittek, B. (2004). Dermcidin is constitutively produced by eccrine sweat glands and is not induced in epidermal cells under inflammatory skin conditions. British Journal of Dermatology, Vol. 151, No. 3, pp. 534-539, ISSN 0007-0963

Rodrigues, EG., Dobroff, AS., Cavarsan, CF., Paschoalin, T., Nimrichter, L., Mortara, RA., Santos, EL., Fázio, MA., Miranda, A., Daffre, S., \& Travassos, LR. (2008). Effective topical treatment of subcutaneous murine B16F10-Nex2 melanoma by the antimicrobial peptide gomesin. Neoplasia, Vol. 10, No. 1, pp. 61-68, ISSN 1522-8002

Rodríguez-Hernández, MJ., Saugar, J., Docobo-Pérez, F., de la Torre, BG., Pachón-Ibáñez, ME., García-Curiel, A., Fernández-Cuenca, F., Andreu D., Rivas, L., \& Pachón, J. (2006). Studies on the antimicrobial activity of cecropin A-melittin hybrid peptides in colistin-resistant clinical isolates of Acinetobacter baumannii. Journal of Antimicrobial Chemotherapy, Vol. 58, No. 1, pp. 95-100, ISSN 0305-7453

Rokitskaya, TI., Kolodkin, NI., Kotova, EA., \& Antonenko, YN. (2011). Indolicidin action on membrane permeability: Carrier mechanism versus pore formation. Biochimica et Biophysica Acta, Vol. 1808, No. 1, pp. 91-97, ISSN 0006-3002

Rollema, HS., Kuipers, OP., Both, P., de Vos, WM., \& Siezen, RJ. (1995). Improvement of solubility and stability of the antimicrobial peptide nisin by protein engineering. Applied and Environmental Microbiology, Vol. 61, No. 8, pp. 2873-2878, ISSN 00992240

Romanelli, A., Moggio, L., Montella, RC., Campiglia, P., Iannaccone, M., Capuano, F., Pedone, C., \& Capparelli, R. (2011). Peptides from Royal Jelly: studies on the antimicrobial activity of jelleins, jelleins analogs and synergy with temporins. Journal of Peptide Science, Vol. 17, No. 5, pp. 348-352, ISSN 1075-2617

Romeo, D., Skerlavaj, B., Bolognesi, M., \& Gennaro, R. (1988). Structure and bactericidal activity of an antibiotic dodecapeptide purified from bovine neutrophils. The Journal of Biological Chemistry, Vol. 263, No. 20, (Jul 15), pp. 9573-9575, ISSN 00219258 
Ross, AC.; \& Vederas, JC. (2011). Fundamental functionality: recent developments in understanding the structure-activity relationships of lantibiotic peptides. The Journal of Antibiotics, Vol. 64, No. 1, pp. 27-34, ISSN 0021-8820

Roy, H., Dare, K., \& Ibba, M. Adaptation of the bacterial membrane to changing environments using aminoacylated phospholipids. Molecular Microbiology. (2009) Vol. 71, No. 3, pp. 547-550, ISSN 0950-382X

Rubinchik, E., Dugourd, D., Algara, T., Pasetka, C., \& Friedland, HD. (2009). Antimicrobial and antifungal activities of a novel cationic antimicrobial peptide, omiganan, in experimental skin colonisation models. International Journal of Antimicrobial Agents, Vol. 34, No. 5, pp. 457-461, ISSN 0924-8579

Ryan, LK., Dai J., Yin, Z., Megjugorac, N., Uhlhorn, V., Yim, S., Schwartz, KD., Abrahams, JM., Diamond, G., \& Fitzgerald-Bocarsly, P. (2011). Modulation of human \{beta\}defensin-1 (hBD-1) in plasmacytoid dendritic cells (PDC), monocytes, and epithelial cells by influenza virus, Herpes simplex virus, and Sendai virus and its possible role in innate immunity. Journal of Leukocyte Biology, May 6, Epub ahead of print, ISSN 0741-5400

Ryu, S., Choi, SY., Acharya, S., Chun, YJ., Gurley, C., Park, Y., Armstrong, CA., Song, PI., Kim, BJ. (2011). Antimicrobial and Anti-Inflammatory Effects of Cecropin A(1-8)Magainin2(1-12) Hybrid Peptide Analog P5 against Malassezia furfur Infection in Human Keratinocytes. Journal of Investigative Dermatology, Vol. 131, No. 8, pp. 16771683, ISSN 0022-202X

Sánchez-Hidalgo, M., Montalbán-López, M., Cebrián, R., Valdivia, E., Martínez-Bueno, M., Maqueda, M. (2011). AS-48 bacteriocin: close to perfection. Cellular and Molecular Life Sciences. May 17, Epub ahead of print, ISSN 1420-682X

Saravanan, R., \& Bhattacharjya, S. (2011). Oligomeric structure of a cathelicidin antimicrobial peptide in dodecylphosphocholine micelle determined by NMR spectroscopy. Biochimica et Biophysica Acta, Vol. 1808, No. 1, pp. 369-381, ISSN 00063002

Savoia, D., Guerrini, R., Marzola, E., \& Salvadori, S. (2008). Synthesis and antimicrobial activity of dermaseptin S1 analogues. Bioorganic $\mathcal{E}$ Medicinal Chemistry, Vol. 16, No. 17, pp. 8205-8209, ISSN 0968-0896

Savoia, D., Donalisio, M., Civra, A., Salvadori, S., \& Guerrini, R. (2010). In vitro activity of dermaseptin S1 derivatives against genital pathogens. Acta Pathologica, Microbiologica et Immunologica Scandinavica, Vol. 118, No. 9, pp. 674-680, ISSN 09034641

Schittek, B., Hipfel, R., Sauer, B., Bauer, J., Kalbacher, H., Stevanovic, S., Schirle, M., Schroeder, K., Blin, N., Meier, F., Rassner, G., \& Garbe, C. (2001). Dermcidin: a novel human antibiotic peptide secreted by sweat glands. Nature Immunology, Vol. 2, No. 12, pp. 1133-1137, ISSN 1529-2908

Schittek, B., Paulmann, M., Senyürek, I., \& Steffen, H. (2008). The role of antimicrobial peptides in human skin and in skin infectious diseases. Infectious Disorders Drug Targets, Vol. 8, No. 3, pp. 135-143, ISSN 1871-5265

Schneider, T., Kruse, T., Wimmer, R., Wiedemann, I., Sass, V., Pag, U., Jansen, A., Nielsen, AK., Mygind, PH.; Raventós, DS., Neve, S., Ravn, B., Bonvin, AM., De Maria, L., Andersen, A.S., Gammelgaard, LK., Sahl, HG., \& Kristensen, HH. (2010). Plectasin, 
a fungal defensin, targets the bacterial cell wall precursor Lipid II. Science, Vol. 328, No. 5982, pp. 1168-1172, ISSN 0036-8075

Schuch, R., Nelson, D., \& Fischetti, VA. (2002). A bacteriolytic agent that detects and kills Bacillus anthracis. Nature, Vol. 418, No. 6900, pp. 884-889, ISSN 0028-0836

Schutte, BC., Mitros, JP., Bartlett, JA., Walters, JD., Jia, HP., Welsh, MJ., Casavant, TL., \& McCray, PB. Jr. (2002). Discovery of five conserved beta -defensin gene clusters using a computational search strategy. Proceedings of the National Academy of Sciences USA, Vol. 99, No. 4, (Feb 19), pp. 2129-2133, ISSN 0027-8424

Schweizer, F. (2009). Cationic amphiphilic peptides with cancer-selective toxicity. European Journal of Pharmacology, Vol. 625, No. 1-3, (Dec 25), pp. 190-194, ISSN 0014-2999

Scott, MG., Davidson, DJ., Gold, MR., Bowdish, D., \& Hancock, RE. (2002). The human antimicrobial peptide LL-37 is a multifunctional modulator of innate immune responses. The Journal of Immunology, Vol. 169, No. 7, pp. 3883-3891, ISSN 0022-1767

Scott, MG., Dullaghan, E., Mookherjee, N., Glavas, N., Waldbrook, M., Thompson, A., Wang, A., Lee, K., Doria, S., Hamill, P., Yu, JJ., Li, Y., Donini, O., Guarna, MM., Finlay, BB., North, JR., \& Hancock, RE. (2007). An anti-infective peptide that selectively modulates the innate immune response. Nature Biotechnology, Vol. 25, No. 4, pp. 465-472, ISSN 1087-0156

Scott, RW., DeGrado, WF., \& Tew, GN. (2008). De novo designed synthetic mimics of antimicrobial peptides. Current Opinion in Biotechnology, Vol. 19, No. 6, pp. 620-627, ISSN 0958-1669

Selsted, ME., Novotny, MJ., Morris, WL., Tang, YQ., Smith, W., \& Cullor, JS. (1992). Indolicidin, a novel bactericidal tridecapeptide amide from neutrophils. The Journal of Biological Chemistry, Vol. 267, No. 7, (Mar 5), pp. 4292-4295, ISSN 0021-9258.

Selsted, ME., \& Ouellette, AJ. (2005). Mammalian defensins in the antimicrobial immune response. Nature Immunology, Vol. 6, No. 6, pp. 551-557, ISSN 1529-2908

Senyürek, I., Paulmann, M., Sinnberg, T., Kalbacher, H., Deeg, M., Gutsmann, T., Hermes, M., Kohler, T., Götz, F., Wolz, C., Peschel, A., \& Schittek, B. (2009). Dermcidinderived peptides show a different mode of action than the cathelicidin LL-37 against Staphylococcus aureus. Antimicrobial Agents and Chemotherapy, Vol. 53, No. 6, pp. 2499-2509, ISSN 0066-4804

Sharma, KR., Reddy, PR., Tegge, W., \& Jain, R. (2009). Discovery of Trp-His and His-Arg analogues as new structural classes of short antimicrobial peptides. The Journal of Medicinal Chemistry, Vol. 52, pp. 7421-7431, ISSN 0022-2623

Silva, PI. Jr., Daffre, S., \& Bulet, P. (2000). Isolation and characterization of gomesin, an 18residue cysteine-rich defense peptide from the spider Acanthoscurria gomesiana hemocytes with sequence similarities to horseshoe crab antimicrobial peptides of the tachyplesin family. The Journal of Biological Chemistry, Vol. 275, No. 43, (Oct 27), pp. 33464-33470, ISSN 0021-9258

Simmaco, M., Mignogna, G., Canofeni, S., Miele, R., Mangoni, ML., \& Barra, D. (1996). Temporins, antimicrobial peptides from the European red frog Rana temporaria. European Journal of Biochemistry, Vol. 242, No. 3, pp. 788-792, ISSN 0014-2956

Soravia, E., Martini, G., \& Zasloff, M. (1988). Antimicrobial properties of peptides from Xenopus granular gland secretions. FEBS Letters, Vol. 228, pp. 337-340, ISSN 00145793. 
Spellberg, B., Guidos, R., Gilbert, D., Bradley, J., Boucher, HW., Scheld, WM., Bartlett, JG. \& Edwards J. Jr. (2008). Infectious Diseases Society of America. The epidemic of antibiotic-resistant infections: a call to action for the medical community from the Infectious Diseases Society of America. Clinical Infectious Diseases, Vol. 46, No. 2, (Jan 15), pp. 155-164, ISSN 1058-4838

Spencer, JD., Schwaderer, AL., Dirosario, JD., McHugh, KM., McGillivary, G., Justice, SS., Carpenter, AR., Baker, PB., Harder, J., \& Hains, DS. (2011). Ribonuclease 7 is a potent antimicrobial peptide within the human urinary tract. Kidney International, Vol. 80, No. 2, pp. 174-180, ISSN 0085-2538

Storici, P., \& Zanetti, M. (1993). A cDNA derived from pig bone marrow cells predicts a sequence identical to the intestinal antibacterial peptide PR-39. Biochemical and Biophysical Research Communications, Vol. 196, No. 3, (Nov 15), pp. 1058-65, ISSN 0006-291X

Tagg, JR., Dajani, AS., \& Wannamaker, LW. (1976). Bacteriocins of gram-positive bacteria. Bacteriological Reviews, Vol. 40, No. 3, pp. 722-756, ISSN 0005-3678

Termorshuizen, F., Garssen, J., Norval, M., Koulu, L., Laihia, J., Leino, L., Jansen, CT., De Gruijl, F., Gibbs, NK., De Simone, C., \& Van Loveren, H. (2002). A review of studies on the effects of ultraviolet irradiation on the resistance to infections: evidence from rodent infection models and verification by experimental and observational human studies. International Immunopharmacology, Vol. 2, No. 2-3, pp. 263-275, ISSN 15675769

Tseng, JM., Huang, JR., Huang, HC., Tzen, JT., Chou, WM., \& Peng, CC. (2011). Facilitative production of an antimicrobial peptide royalisin and its antibody via an artificial oil-body system. Biotechnology Progress, Vol. 27, No. 1, pp. 153-161, ISSN 8756-7938

Turpin, ER., Bonev, BB., \& Hirst, JD. (2010). Stereoselective disulfide formation stabilizes the local peptide conformation in nisin mimics. Biochemistry, Vol. 49, No. 44, pp. 95949603, ISSN 0006-2960

van Dijk, A., Veldhuizen, EJ., van Asten, AJ., \& Haagsman, HP. (2005). CMAP27, a novel chicken cathelicidin-like antimicrobial protein. Veterinary Immunology and Immunopathology, Vol. 106, No. 3-4, (Jul 15), pp. 321-327, ISSN 0165-2427

Vanhoye, D., Bruston, F., Nicolas, P., \& Amiche, M. (2003). Antimicrobial peptides from hylid and ranin frogs originated from a 150-million-year-old ancestral precursor with a conserved signal peptide but a hypermutable antimicrobial domain. European Journal of Biochemistry, Vol. 270, No. 9, pp. 2068-2081, ISSN 0014-2956

Venkataraman, N., Cole, AL., Ruchala, P., Waring, AJ., Lehrer, RI., Stuchlik, O., Pohl, J., \& Cole, AM. (2009). Reawakening retrocyclins: ancestral human defensins active against HIV-1: PLoS Biology, Vol. 7, No. 4, e95, ISSN 1932-6203

Verbeken, G., De Vos, D., Vaneechoutte, M., Merabishvili, M., Zizi, M., \& Pirnay, J.P. (2007). European regulatory conundrum of phage therapy. Future Microbiology, Vol. 2, pp. 485-491, ISSN 1746-0913

Verma, V., Harjai, K., \& Chhibber, S. (2009). Characterization of a T7-like lytic bacteriophage of Klebsiella pneumoniae B5055: a potential therapeutic agent. Current Microbiology, Vol. 59, No. 3, pp. 274-281, ISSN 0343-8651

Wakabayashi, T., Kato, H., \& Tachibana, S. (1985). Complete nucleotide sequence of mRNA for caerulein precursor from Xenopus skin: the mRNA contains an unusual 
repetitive structure. Nucleic Acids Research, Vol. 13, No. 6, (Mar 25), pp. 1817-28, ISSN 0305-1048

Walsh, CT., \& Fischbach, MA. (2010). Natural products version 2.0: connecting genes to molecules. Journal of the American Chemical Society, Vol. 132, No. 8, (Mar 3), pp. 246993, ISSN 0002-7863

Wang, G., Li, X., \& Wang, Z. (2009). APD2: the updated antimicrobial peptide database and its application in peptide design. Nucleic Acids Research, Vol. 37, (Database issue), pp. D933-D937, ISSN 0305-1048

Wang, M., Liu, LH., Wang, S., Li, X., Lu, X., Gupta, D, \& Dziarski, R. (2007). Human peptidoglycan recognition proteins require zinc to kill both gram-positive and gram-negative bacteria and are synergistic with antibacterial peptides. The Journal of Immunology, Vol. 178, No. 5, (Mar 1), pp. 3116-3125, ISSN 0022-1767

Welte, T., \& Pletz, MW. (2010). Antimicrobial treatment of nosocomial meticillin-resistant Staphylococcus aureus (MRSA) pneumonia: current and future options. International Journal of Antimicrobial Agents, Vol. 36, No. 5, pp. 391-400, ISSN 0924-8579

Wencker, M., \& Brantly, ML. (2005). Cytotoxic concentrations of alpha-defensins in the lungs of individuals with alpha 1-antitrypsin deficiency and moderate to severe lung disease. Cytokine, Vol. 32, No. 1, pp. 1-6, ISSN 1043-4666

White, JH. (2010). Vitamin D as an inducer of cathelicidin antimicrobial peptide expression: past, present and future. The Journal of Steroid Biochemistry and Molecular Biology, Vol. 121, No. 1-2, pp. 234-238, ISSN 0960-0760.

Wiesner, J., \& Vilcinskas, A. (2010). Antimicrobial peptides: the ancient arm of the human immune system. Virulence, Vol. 1, No. 5, pp. 440-464, ISSN 2150-5594

Wilmes, M., Cammue, BP., Sahl, HG., \& Thevissen, K. (2011). Antibiotic activities of host defense peptides: more to it than lipid bilayer perturbation. Natural Products Reports, May 27, Epub ahead of print, ISSN 0265-0568

Witzenrath, M., Schmeck, B., Doehn, JM., Tschernig, T., Zahlten, J., Loeffler, JM., Zemlin, M., Müller, H., Gutbier, B., Schütte, H., Hippenstiel, S., Fischetti, VA.; Suttorp, N., \& Rosseau, S. (2009). Systemic use of the endolysin Cpl-1 rescues mice with fatal pneumococcal pneumonia. Critical Care Medicine, Vol. 37, No. 2, pp. 642-649, ISSN 0090-3493

Wohlford-Lenane, CL., Meyerholz, DK., Perlman, S., Zhou, H., Tran, D., Selsted, ME., \& McCray, PB. Jr. (2009). Rhesus theta-defensin prevents death in a mouse model of severe acute respiratory syndrome coronavirus pulmonary disease. The Journal of Virology, Vol. 83, No. 21, pp. 11385-11390, ISSN 0022-538X

Woosley, LN., Castanheira, M., \& Jones, RN. (2010). CEM-101 activity against Grampositive organisms. Antimicrobial Agents and Chemotherapy, Vol. 54, pp. 2182-2187, ISSN 0066-4804

World Health Organization. (2004). Deaths by cause, sex and mortality stratum in WHO regions, estimates for 2002: World Health Report-2004. Geneva: World Health Organization.

Wright, A., Hawkins, CH., Anggård, EE., \& Harper, DR. (2009). A controlled clinical trial of a therapeutic bacteriophage preparation in chronic otitis due to antibiotic-resistant Pseudomonas aeruginosa; a preliminary report of efficacy. Clinical Otolaryngology, Vol. 34, No. 4, pp. 349-357, ISSN 0307-7772 
Wu, JM., Jan, PS., Yu, HC., Haung, HY., Fang, HJ., Chang, YI., Cheng, JW., \& Chen, HM. (2009). Structure and function of a custom anticancer peptide, CB1a. Peptides, Vol. 30, No. 5, pp. 839-848, ISSN 0196-9781

Xiao, Y., Cai, Y., Bommineni, YR., Fernando, SC., Prakash, O., Gilliland, SE., \& Zhang, G. (2006). Identification and functional characterization of three chicken cathelicidins with potent antimicrobial activity. The Journal of Biological Chemistry, Vol. 281, No. 5, (Feb 3), pp. 2858-2867, ISSN 0021-9258

Xiao, Y., Herrera, AI., Bommineni, YR., Soulages, JL., Prakash, O., \& Zhang, G. (2009). The central kink region of fowlicidin-2, an alpha-helical host defense peptide, is critically involved in bacterial killing and endotoxin neutralization. Journal of Innate Immunity, Vol. 1, No. 3, pp. 268-280, ISSN 1662-811X

Yoshida, H., Kinoshita, K., \& Ashida, M. (1996). Purification of a peptidoglycan recognition protein from hemolymph of the silkworm, Bombyx mori. The Journal of Biological Chemistry, Vol. 271, No. 23, (Jun 7), pp. 13854-13860, ISSN 0021-9258

Zairi, A., Tangy, F., Ducos-Galand, M., Alonso, JM., \& Hani, K. (2007). Susceptibility of Neisseria gonorrhoeae to antimicrobial peptides from amphibian skin, dermaseptin, and derivatives. Diagnostic Microbiology and Infectious Diseases, Vol. 57, No. 3, pp. 319-324, ISSN 0732-8893

Zanetti, M. (2005). The role of cathelicidins in the innate host defenses of mammals. Current Issues in Molecular Biology, Vol. 7, No. 2, pp. 179-196, ISSN 1467-3037

Zangger, K., Gössler, R., Khatai, L., Lohner, K., \& Jilek, A. (2008). Structures of the glycinerich diastereomeric peptides bombinin $\mathrm{H} 2$ and H4. Toxicon, Vol. 52, No. 2, (Aug 1), pp. 246-254, ISSN 0041-0101

Zasloff, M. (1987). Magainins, a class of antimicrobial peptides from Xenopus skin: isolation, characterization of two active forms, and partial cDNA sequence of a precursor. Proceedings of the National Academy of Sciences USA, Vol. 84, No. 15, pp. 5449-53, ISSN 0027-8424

Zasloff, M. (2002). Antimicrobial peptides of multicellular organisms. Nature, Vol. 415, pp. 389-395, ISSN 0028-0836

Zhanel, GG., Calic, D., Schweizer, F., Zelenitsky, S., Adam, H., Lagacé-Wiens, PR., Rubinstein, E., Gin, AS., Hoban, DJ., \& Karlowsky, JA. (2010). New lipoglycopeptides: a comparative review of dalbavancin, oritavancin and telavancin. Drugs, Vol. 70, No. 7, pp. 859-886, ISSN 0012-6667

Zhang, Y., Zhao, H., Yu, G.Y., Liu, X.D., Shen, J.H., Lee, W.H., \& Zhang Y. (2010). Structurefunction relationship of king cobra cathelicidin. Peptides, Vol. 31, No. 8, pp. 14881493, ISSN 0196-9781

Zhao, H., Gan, TX., Liu, XD., Jin, Y., Lee, WH., Shen, JH., \& Zhang, Y. (2008). Identification and characterization of novel reptile cathelicidins from elapid snakes. Peptides, Vol. 29, No. 10, pp. 1685-1691, ISSN 0196-9781

Zhu, S. (2007). Evidence for myxobacterial origin of eukaryotic defensins. Immunogenetics, Vol. 59, No. 12, pp. 949-954, ISSN 0093-7711

Zhu, S. (2008). Did cathelicidins, a family of multifunctional host-defense peptides, arise from a cysteine protease inhibitor? Trends in Microbiology, Vol. 16, No. 8, pp. 353360, ISSN 0966-842X 


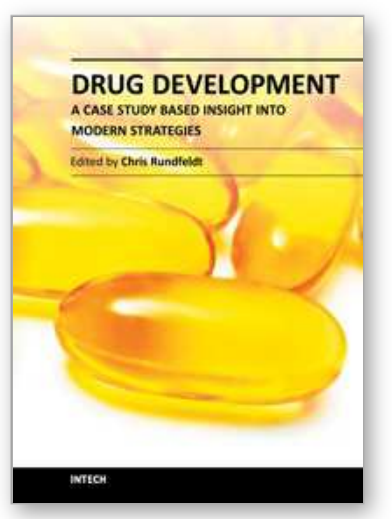

\author{
Drug Development - A Case Study Based Insight into Modern \\ Strategies \\ Edited by Dr. Chris Rundfeldt
}

ISBN 978-953-307-257-9

Hard cover, 654 pages

Publisher InTech

Published online 07, December, 2011

Published in print edition December, 2011

This book represents a case study based overview of many different aspects of drug development, ranging from target identification and characterization to chemical optimization for efficacy and safety, as well as bioproduction of natural products utilizing for example lichen. In the last section, special aspects of the formal drug development process are discussed. Since drug development is a highly complex multidisciplinary process, case studies are an excellent tool to obtain insight in this field. While each chapter gives specific insight and may be read as an independent source of information, the whole book represents a unique collection of different facets giving insight in the complexity of drug development.

\title{
How to reference
}

In order to correctly reference this scholarly work, feel free to copy and paste the following:

Mario Zucca, Sara Scutera and Dianella Savoia (2011). Antimicrobial Peptides: New Frontiers in the Therapy of Infections, Drug Development - A Case Study Based Insight into Modern Strategies, Dr. Chris Rundfeldt (Ed.), ISBN: 978-953-307-257-9, InTech, Available from: http://www.intechopen.com/books/drug-developmenta-case-study-based-insight-into-modern-strategies/antimicrobial-peptides-new-frontiers-in-the-therapy-ofinfections

\section{INTECH}

open science | open minds

\section{InTech Europe}

University Campus STeP Ri

Slavka Krautzeka 83/A

51000 Rijeka, Croatia

Phone: +385 (51) 770447

Fax: +385 (51) 686166

www.intechopen.com

\section{InTech China}

Unit 405, Office Block, Hotel Equatorial Shanghai

No.65, Yan An Road (West), Shanghai, 200040, China

中国上海市延安西路65号上海国际贵都大饭店办公楼405单元

Phone: $+86-21-62489820$

Fax: $+86-21-62489821$ 
(C) 2011 The Author(s). Licensee IntechOpen. This is an open access article distributed under the terms of the Creative Commons Attribution 3.0 License, which permits unrestricted use, distribution, and reproduction in any medium, provided the original work is properly cited. 